\title{
Role of ALD Al2O3 Surface Passivation on the Performance of p-Type Cu2O Thin Film Transistors
}

\section{Napari, Mari}

2021-01-27

Napari , M , Huq , T N, Meeth , D J , Heikkilä , M J , Niang , K M , Wang , H, livonen , T, Wang , H , Leskelä , M , Ritala , M , Flewitt , A J , Hoye , R L Z \& MacManus-Driscoll , J L 2021 , ' Role of ALD Al2O3 Surface Passivation on the Performance of $p$-Type Cu2O Thin

Film Transistors ' , ACS Applied Materials \& Interfaces , vol. 13 , no. 3 , pp. 4156-4164 . https://doi.org/10.1021/acsa

http://hdl.handle.net/10138/338592

https://doi.org/10.1021/acsami.0c18915

acceptedVersion

Downloaded from Helda, University of Helsinki institutional repository.

This is an electronic reprint of the original article.

This reprint may differ from the original in pagination and typographic detail.

Please cite the original version. 


\title{
Role of $\mathrm{ALD} \mathrm{Al}_{2} \mathrm{O}_{3}$ surface passivation on the
}

\section{performance of p-type $\mathrm{Cu}_{2} \mathrm{O}$ thin film transistors}

\author{
Mari Napari, ${ }^{* \dagger,}, \perp$ Tahmida N. Huq, ${ }^{\dagger}$ David J. Meeth ${ }^{\ddagger}{ }^{\ddagger}$ Mikko J. Heikkilä, $₫$ Kham \\ M. Niang, ${ }^{\ddagger}$ Han Wang,,$§$ Tomi livonen, $₫, \#$ Haiyan Wang," Markku Leskelä, \\ Mikko Ritala, ${ }^{\top}$ Andrew J. Flewitt, ${ }^{\ddagger}$ Robert L. Z. Hoye, ${ }^{\dagger} @$ and Judith L. \\ MacManus-Driscoll ${ }^{\dagger}$
}

$\dagger$ Department of Materials Science and Metallurgy, University of Cambridge, Cambridge CB3 OFS, UK

$\ddagger$ Electrical Engineering Division, Department of Engineering, University of Cambridge, Cambridge CB3 OFA, UK

IDepartment of Chemistry, University of Helsinki, FI-00014 Helsinki, FIN

$\S$ Materials Engineering, Purdue University, IN 47907, US

\|School of Materials Engineering, Purdue University, IN 47907, US

$\perp$ Present address: Zepler Institute for Photonics and Nanoelectronics, University of Southampton, Southampton SO17 1BJ, UK

\#Present address: Nanoform Finland Oyj, FI-00790 Helsinki, FIN

@ Present address: Department of Materials, Imperial College London, London SW7 2AZ, $U K$

E-mail: m.p.napari@soton.ac.uk

\begin{abstract}
High-performance p-type oxide thin film transistors (TFTs) have great potential for many semiconductor applications. However, these devices typically suffer from low
\end{abstract}


hole mobility and high off-state currents. We fabricated p-type TFTs with a phasepure polycrystalline $\mathrm{Cu}_{2} \mathrm{O}$ semiconductor channel grown by atomic layer deposition (ALD). The TFT switching characteristics were improved by applying a thin ALD $\mathrm{Al}_{2} \mathrm{O}_{3}$ passivation layer on the $\mathrm{Cu}_{2} \mathrm{O}$ channel, followed by vacuum annealing at $300{ }^{\circ} \mathrm{C}$. Detailed characterisation by TEM-EDX and XPS shows that the surface of $\mathrm{Cu}_{2} \mathrm{O}$ is reduced following $\mathrm{Al}_{2} \mathrm{O}_{3}$ deposition and indicates the formation of 1-2 $\mathrm{nm}$ thick $\mathrm{CuAlO}_{2}$ interfacial layer. This, together with field-effect passivation caused by the high negative fixed charge of the $\mathrm{ALD} \mathrm{Al}_{2} \mathrm{O}_{3}$, leads to an improvement in the TFT performance by reducing the density of deep trap states as well as by reducing the accumulation of electrons in the semiconducting layer in the device off-state.

Keywords: Thin film transistors, oxide thin films, passivation, copper oxide, atomic layer deposition

\section{Introduction}

Metal-oxide thin film transistors (TFTs) have attracted increasing interest especially in display technologies owing to their optical transparency and high mobility, low processing temperatures and material costs, and mechanical flexibility. ${ }^{1}$ This has led to the development of high-performance n-type semiconducting oxide materials, such as amorphous indiumgallium-zinc-oxide (IGZO) with electron mobility of several tens of $\mathrm{cm}^{2} \mathrm{~V}^{-1} \mathrm{~s}^{-1} \cdot{ }^{2}$ However, the full utilisation of oxides in p-n junction based electronics and complementary metal oxide semiconductor (CMOS) integrated circuits, is still hindered by the lack of high performance p-type oxides. The reason for the challenges in achieving feasible hole conductivity are the differences in the electronic structures of the $n$ - and p-type oxides. ${ }^{3}$ The transport path of holes in p-type oxides, valence band maximum (VBM) consists typically of localised anisotropic oxygen 2 p orbitals, which results in large hole effective mass and low mobility. In addition, the concentration of holes in oxides is often limited by the high formation energy of the cation vacancies, as well as the annihilation of holes due to the low formation 
energy of the oxygen vacancies. ${ }^{3}$ In case of cuprous oxide $\mathrm{Cu}_{2} \mathrm{O}$, however, the valence band is formed by the hybridisation of the $\mathrm{O} 2 \mathrm{p}$ and $\mathrm{Cu} 3 \mathrm{~d}$ orbitals, resulting in a less localized VBM and pathway for hole transportation for holes formed via copper vacancies $\left(\mathrm{V}_{\mathrm{Cu}}\right)$ as acceptor states. ${ }^{4}$ Such special configuration and high hole mobility have made $\mathrm{Cu}_{2} \mathrm{O}$ an extensively studied p-type oxide for TFTs,${ }^{5}$ and due to to its other advantageous properties, such as material abundance and solar absorbance, it has also been investigated as a potential candidate for multiple device applications ranging from photovoltaics to sensors. ${ }^{6}$

$\mathrm{Cu}_{2} \mathrm{O}$ layers for TFTs are traditionally fabricated by physical vapour deposition (PVD) methods, such as pulsed lased deposition (PLD) $)^{7-9}$ and sputtering. ${ }^{10-12}$ Solution-based processing methods have also been used, such as spin coating, ${ }^{13,14}$ electrodeposition ${ }^{15}$ and inkjet printing. ${ }^{16}$ For scalable device applications it is crucial to be able to deposit films with uniform and controllable thickness and composition over large areas, preferably at low or moderate temperatures. Atomic layer deposition (ALD) has been proven invaluable for the fabrication of modern microelectronics, where it is used to produce ultra-thin high-quality dielectric films for devices including metal-oxide semiconductor field effect transistors (MOSFET) and dynamic random access memories (DRAM). ALD has the potential to be extended in production of active device layers. It has already shown to be capable of depositing ntype semiconducting films, such as IGZO,${ }^{17}$ with properties compatible with what has been achieved by PVD techniques. ${ }^{2,17}$ The successful application of ALD grown n-type semiconducting oxides in TFTs has been demonstrated both on rigid and flexible substrates. ${ }^{18,19}$ Development of ALD processes for p-type materials $\left(\mathrm{NiO}, \mathrm{CuO}_{\mathrm{x}}, \mathrm{SnO}\right)$ has been mostly of interest for photovoltaics, especially in perovskite and tandem solar cells, where they can be used as electron-blocking and hole transport layers. ${ }^{20}$ However, some examples of other electronics applications, such as p-type TFTs with ALD grown semiconductor channels have been published. ${ }^{18,21,22}$ For example, high performing TFTs with $\mathrm{ALD}$ grown $\mathrm{CuO}_{\mathrm{x}}$ films (consisting of both $\mathrm{Cu}_{2} \mathrm{O}$ and $\mathrm{CuO}$ phases) have been reported by Maeng et al. ${ }^{21}$ Their devices showed an unusually high field effect mobility of $\mu_{\mathrm{FE}}=5.6 \mathrm{~cm}^{2} \mathrm{~V}^{-1} \mathrm{~s}^{-1}$, which is higher 
than the $\mu_{\mathrm{FE}}$ of any reported $\mathrm{CuO}_{\mathrm{x}}$ device in the literature. Unfortunately, to our best knowledge, these results have not yet been consistently reproduced, nor are there other reports of the use of ALD $\mathrm{Cu}_{2} \mathrm{O}$ in TFTs. However, ALD was used to demonstrate high-performance p-type TFTs with SnO channel. ${ }^{22}$ There it was observed that applying an $\mathrm{Al}_{2} \mathrm{O}_{3}$ channel passivation significantly improves the TFT performance via the reduction of trap states at the interface.

Here, we investigate the influence of an $\mathrm{ALD} \mathrm{Al}_{2} \mathrm{O}_{3}$ passivation layer on the performance of p-type TFTs with an ALD grown $\mathrm{Cu}_{2} \mathrm{O}$ channel. We show that passivation and subsequent vacuum annealing improve the transistor performance metrics. In addition to device measurements, the $\mathrm{Al}_{2} \mathrm{O}_{3} / \mathrm{Cu}_{2} \mathrm{O}$ interface was characterised in detail by using x-ray photoelectron spectroscopy (XPS) and transmission electron microscopy (TEM) to obtain more information of the interface modification taking place during the deposition of the $\mathrm{Al}_{2} \mathrm{O}_{3}$ on the $\mathrm{Cu}_{2} \mathrm{O}$. Furthermore, we discuss the significance of the interface formation and other passivation mechanisms of the $\mathrm{ALD} \mathrm{Al}_{2} \mathrm{O}_{3}$ film, such as the effect of the high fixed charge, on the improved performance of the $\mathrm{Cu}_{2} \mathrm{O}$ p-channel TFTs.

\section{Results and discussion}

\section{$\mathrm{Cu}_{2} \mathrm{O}$ film characterization}

The X-ray diffraction pattern of a $40 \mathrm{~nm}$ thick $\mathrm{Cu}_{2} \mathrm{O}$ film is presented in Fig. 1(a). The GIXRD revealed that the films were polycrystalline $\mathrm{Cu}_{2} \mathrm{O}$, with the most intense reflections associated to the (200), (111), and (220) planes of the cubic $\mathrm{Cu}_{2} \mathrm{O}$. No trace of $\mathrm{CuO}$ or $\mathrm{Cu}$ were detected, indicating that the films were phase-pure $\mathrm{Cu}_{2} \mathrm{O}$, with crystallite size of ca. $30 \mathrm{~nm}$. The crystalline structure of the films was visible also by AFM (see example Fig. 1(b)) showing the films to have distinct grains in the morphology with a high surface roughness of ca. $4.5 \mathrm{~nm}$ (RMS). Despite the high film roughness, we can assume the films to be continuous, based on the detailed growth analysis of corresponding $\mathrm{ALD} \mathrm{Cu}_{2} \mathrm{O}$ films reported by Iivonen 
et al. in Ref. ${ }^{23}$ Hall effect measurements confirmed the p-type conductivity of the films, with a resistivity of $\rho=300 \Omega \mathrm{cm}$, hole density of $\mathrm{N}=10^{16} \mathrm{~cm}^{-3}$ and Hall mobility $\mu_{\mathrm{H}}$ $=0.6 \mathrm{~cm}^{2} \mathrm{~V}^{-1} \mathrm{~s}^{-1}$. The Hall hole mobility is somewhat lower than what has been reported earlier for $\mathrm{Cu}_{2} \mathrm{O}$ films. However, as-deposited films processed at lower temperatures generally pose a lower hole mobility, in the order of few $\mathrm{cm}^{2} \mathrm{~V}^{-1} \mathrm{~s}^{-15,10,12,24,25}$ as a maximum, than films deposited and/or treated at high temperatures, in which the mobility can reach tens of $\mathrm{cm}^{2} \mathrm{~V}^{-1} \mathrm{~s}^{-13,7}$ but the variation between different reports is vast. In our case the low hole mobility may be due to low film thickness, which, combined with small grain size and high surface roughness, limits the conduction. Han et al. have investigated the role of the $\mathrm{Cu}_{2} \mathrm{O}$ film morphology on the charge carrier characteristics, and they concluded that nanocrystalline structure of thin $\mathrm{Cu}_{2} \mathrm{O}$ films can suggest the presence of potential energy barriers at grain boundaries, leading to effects such as grain boundary scattering, which hinders the hole transport in the thin films. ${ }^{26}$ This is further enhanced by the formation of a conductive $\mathrm{CuO}$ layer onto the grain surfaces. ${ }^{27}$

\section{TFT performance}

The $\mathrm{Cu}_{2} \mathrm{O}$ films were tested as p-channels in simple bottom-gate thin film transistor devices with Au source and drain electrodes and p-Si substrate acting as a common gate (see inset in Fig. 2). The switching characteristics of the as-deposited films without the $\mathrm{Al}_{2} \mathrm{O}_{3}$ passivation layer were negligible as shown in Fig. 2. With a $10 \mathrm{~nm} \mathrm{Al}_{2} \mathrm{O}_{3}$ layer deposited on the $\mathrm{Cu}_{2} \mathrm{O}$ channel the off-state drain current $\left(\left|\mathrm{I}_{\mathrm{DS}}\right|\right)$ at positive gate voltage $\mathrm{V}_{\mathrm{GS}}$ decreased by three orders of magnitude and switching with $\mathrm{I}_{\mathrm{on}} / \mathrm{I}_{\mathrm{off}} \approx 30$ was measured. It has been shown that the gap state density in oxide semiconductor TFTs can be affected by the ambient moisture and oxygen adsorption on the top channel surface, which can be suppressed by the passivation layer. ${ }^{28}$ However, for this effect the type or fabrication method of the passivation layer seems not to be critical, as improvements in the performance of n- and p-type TFTs have been reported with different ALD and solution-processed oxide films as well as with 


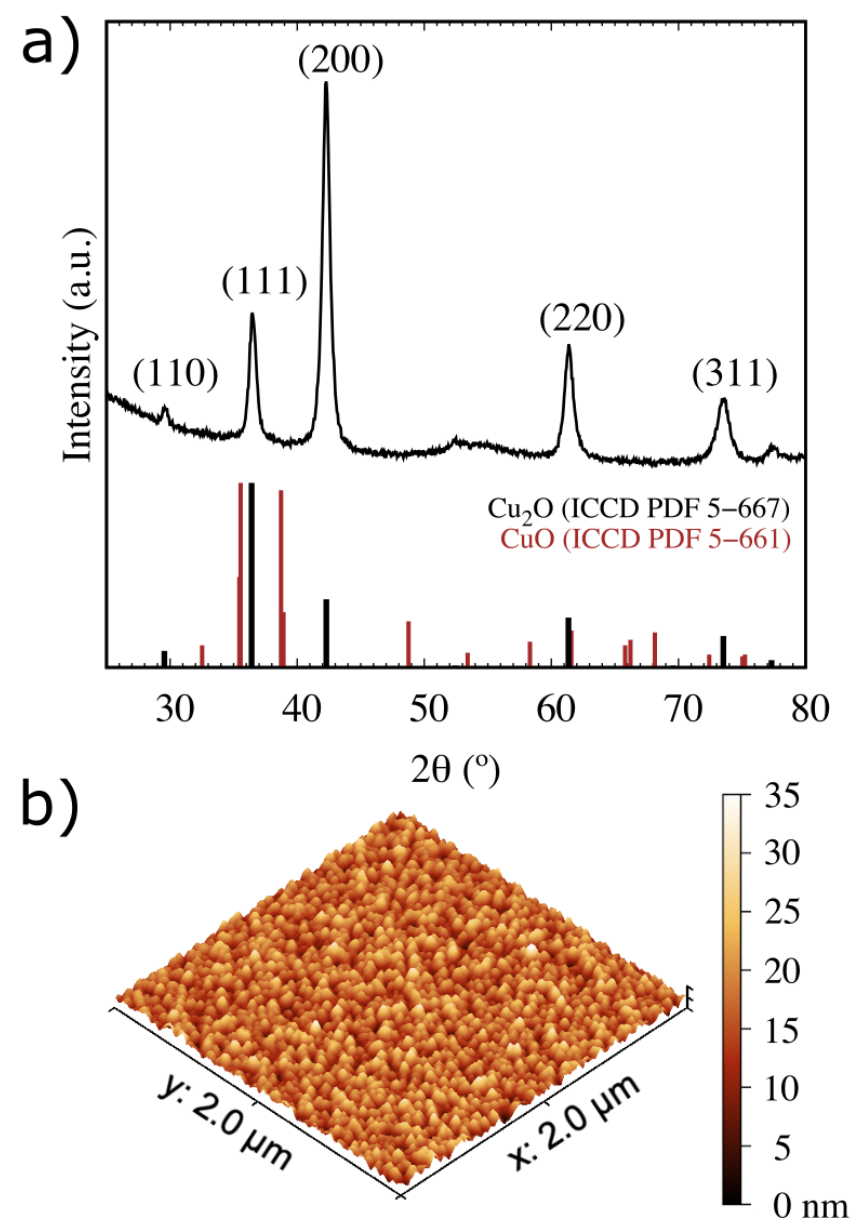

Figure 1: a) XRD pattern of the as-deposited, phase-pure polycrystalline $\mathrm{Cu}_{2} \mathrm{O}$ film and the ICCD cards for both $\mathrm{Cu}_{2} \mathrm{O}$ and $\mathrm{CuO}$, used for indexing. b) 3D AFM image of $2 \mu \mathrm{m} \times 2 \mu \mathrm{m}$ area of the corresponding film. The film roughness (RMS) is $4.5 \mathrm{~nm}$.

organic passivation layers. ${ }^{22,29-31}$

To further improve TFT performance, the devices were annealed for 10 mins in 1.5 mbar $\mathrm{N}_{2}$ directly after $\mathrm{Al}_{2} \mathrm{O}_{3}$ deposition. A low vacuum environment was chosen to prevent phase transitions of the $\mathrm{Cu}_{2} \mathrm{O}$ layer into $\mathrm{CuO}$ or $\mathrm{Cu}$. As seen in Fig 3(a) the transfer characteristics of the devices started to improve after annealing at $250{ }^{\circ} \mathrm{C}$, but the most significant effect was gained at $300{ }^{\circ} \mathrm{C}$, with output characteristics shown in Fig. 3(b). At higher annealing temperatures transfer characteristics begun to deteriorate. In the devices annealed at $400{ }^{\circ} \mathrm{C}$ no switching was observed, and a positive $\mathrm{I}_{\mathrm{DS}}$ was recorded (data not shown). In the unpatterned $\mathrm{Al}_{2} \mathrm{O}_{3} / \mathrm{Cu}_{2} \mathrm{O}$ film reference sample on glasss the $400{ }^{\circ} \mathrm{C}$ annealing caused 


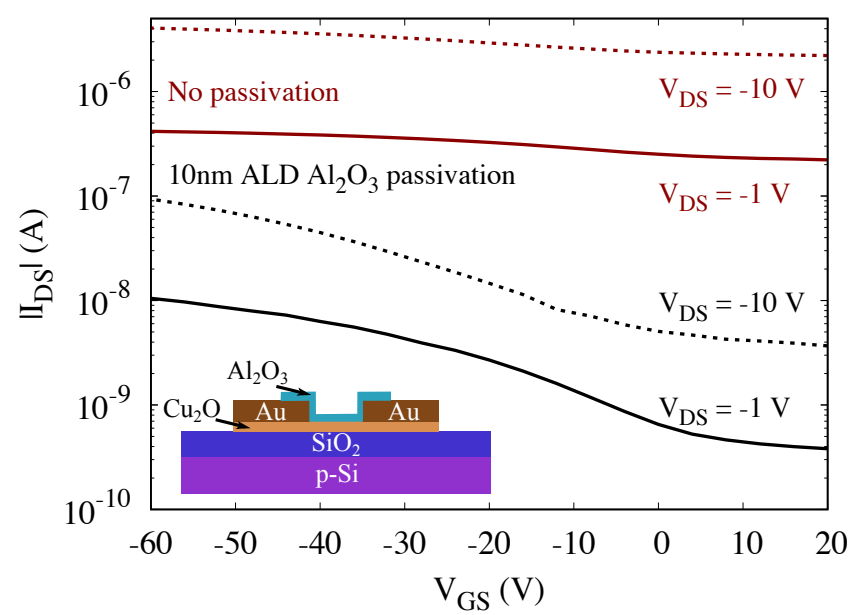

Figure 2: Gate transfer characteristics of a TFT device with $40 \mathrm{~nm} A L D \mathrm{Cu}_{2} \mathrm{O}$ p-channel, with and without $\mathrm{Al}_{2} \mathrm{O}_{3}$ passivation, shown as black and dark-red curves, respectively. In both cases the device is measured with drain voltages $\left(\mathrm{V}_{\mathrm{DS}}\right)$ of $-10.0 \mathrm{~V}$ (dashed lines) and $-1.0 \mathrm{~V}$ (solid lines). Inset shows the schematic of the TFT device with $\mathrm{Al}_{2} \mathrm{O}_{3}$ passivation layer.

color changes visible to the naked eye, potentially indicating a partial reduction into metallic $\mathrm{Cu}$. The same effect was observed also when the annealing was performed in $1 \mathrm{~atm} \mathrm{Ar}$ atmosphere at the same temperature.

Despite the increase in the switching ratio of up to $\mathrm{I}_{\mathrm{on}} / \mathrm{I}_{\mathrm{off}}=5 \cdot 10^{3}$ in the sample annealed at $300{ }^{\circ} \mathrm{C}$, the carrier mobility remained low, with field-effect mobility for the as-deposited and annealed devices being $\mu_{\mathrm{FE}} \approx 1.5 \cdot 10^{-3} \mathrm{~cm}^{2} \mathrm{~V}^{-1} \mathrm{~s}^{-1}$, which was calculated as $\mu_{\mathrm{FE}}=\left(g_{m} L\right) /\left(W C_{\mathrm{ox}} V_{\mathrm{DS}}\right)$, where $g_{m}$ is the transconductance $\left(g_{m}=\delta I_{\mathrm{DS}} / \delta V_{\mathrm{GS}}\right), L$ and $W$ the channel length and width, respectively, $(L=50 \mu \mathrm{m}, W=1000 \mu \mathrm{m})$, and $C_{\mathrm{ox}}$ the gate dielectric capacitance per unit area, calculated using a dielectric constant of 3.9 for $\mathrm{SiO}_{2}$ gate oxide. Additionally, high operating voltages were required for switching, even for devices with enhanced characteristics, with a threshold voltage $V_{\mathrm{TH}}$ and subthreshold swing SS of $-19.8 \mathrm{~V}$ and $11.5 \mathrm{~V} \mathrm{dec}^{-1}$, respectively. The corresponding $\mathrm{V}_{\mathrm{TH}}$ and $\mathrm{SS}$ of the as-deposited device with $\mathrm{Al}_{2} \mathrm{O}_{3}$ passivation were $-13.0 \mathrm{~V}$ and $29.2 \mathrm{~V} \mathrm{dec}^{-1}$, respectively.

The characteristics of the TFTs without the $\mathrm{Al}_{2} \mathrm{O}_{3}$ layer were not improved upon annealing, and Hall effect measurements showed there to be no change in the carrier mobility of the annealed $\mathrm{Cu}_{2} \mathrm{O}$ samples (Fig. $\mathrm{S} 1$ in the Supporting Information). Therefore, it can 

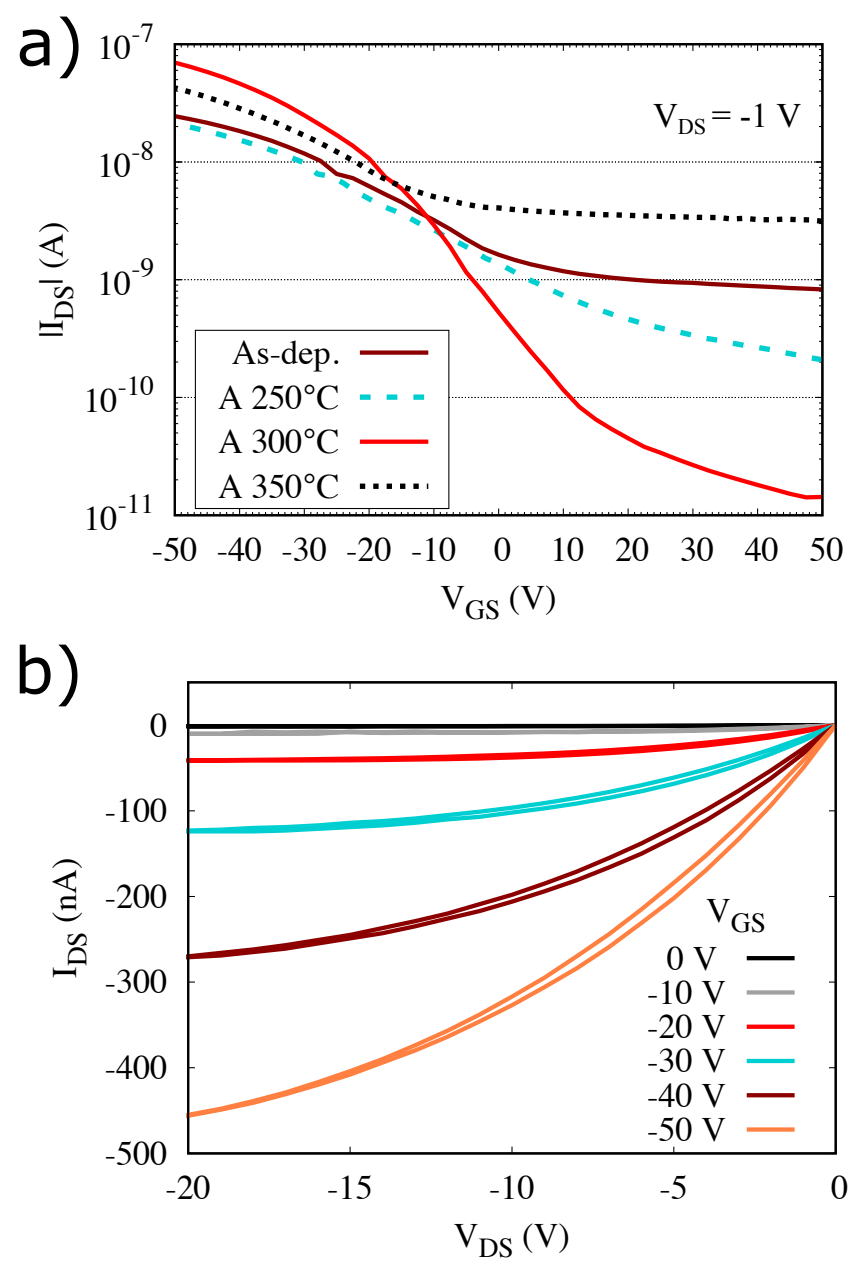

Figure 3: (a) Transfer characteristics of the $\mathrm{Cu}_{2} \mathrm{O}$ TFTs with $\mathrm{Al}_{2} \mathrm{O}_{3}$ passivation, annealed in low-vacuum at different temperatures. Measured with $\mathrm{V}_{\mathrm{DS}}=-1.0 \mathrm{~V}$. (b) Output characteristics of a device annealed at $300{ }^{\circ} \mathrm{C}$.

be concluded that the $\mathrm{Al}_{2} \mathrm{O}_{3}$ passivation is the reason for the improved performance. Similar effects have been reported for p-type TFTs with passivated $\mathrm{SnO}$ channels. ${ }^{22,32} \mathrm{Kim}$ et al. showed an improvement in devices with $\mathrm{ALD} \mathrm{SnO}$ channel passivated with $\mathrm{ALD} \mathrm{Al}_{2} \mathrm{O}_{3}$, which was further enhanced by subsequent annealing. ${ }^{22}$ Similar observations were made by $\mathrm{Qu}$ et al., who passivated sputtered $\mathrm{SnO}$ channels by $\mathrm{ALD} \mathrm{Al}_{2} \mathrm{O}_{3}$ as well as with organic coatings. ${ }^{32}$ Our results are consistent with these findings, both reporting an increase in the $\mathrm{I}_{\mathrm{on}} / \mathrm{I}_{\text {off }}$ ratio and a decrease in $\mathrm{SS}$ upon $\mathrm{ALD} \mathrm{Al}_{2} \mathrm{O}_{3}$ passivation. These changes can be associated with a reduction in the trap state density at the channel surface. It seems that the ALD $\mathrm{Al}_{2} \mathrm{O}_{3}$ passivation has more impact on reducing the deep trap state density, both in 
the $\mathrm{Cu}_{2} \mathrm{O}$ and $\mathrm{SnO}$, indicated by the reduction in the SS. On the other hand, the shallow traps (tail states near the valence band), are less affected, as the the carrier mobility does not increase significantly. ${ }^{32}$ Interestingly, it has been reported ${ }^{29}$ that passivation of n-type oxide TFTs by ALD $\mathrm{Al}_{2} \mathrm{O}_{3}$ increases the mobility and SS which is opposite to what has been observed for the p-type devices.

The low field-effect mobility in the order of $\mu_{\mathrm{FE}}=10^{-3}-10^{-2} \mathrm{~cm}^{2} \mathrm{~V}^{-1} \mathrm{~s}^{-1}$ is typical for $\mathrm{Cu}_{2} \mathrm{O}$ TFTs processed at low/moderate temperatures and with thin channel layer of few tens of $\mathrm{nm}$, regardless of the deposition technique. ${ }^{3,10,14}$ However, there are some reports where orders of magnitude higher $\mu_{\mathrm{FE}}$ values, up to $6 \mathrm{~cm}^{2} \mathrm{~V}^{-1} \mathrm{~s}^{-1}$ have been achieved, even with a room-temperature processing and mixed phase $\mathrm{Cu}_{2} \mathrm{O}-\mathrm{CuO}$ films. ${ }^{21,33}$ The limited mobility in $\mathrm{Cu}_{2} \mathrm{O}$ thin films is typically associated with the high density of subgap trap states and grain boundary scattering. ${ }^{3,26}$ Additionally, it has been shown that a $\mathrm{CuO}$ layer can form at the $\mathrm{Cu}_{2} \mathrm{O} / \mathrm{SiO}_{2}$ interface already at $300{ }^{\circ} \mathrm{C}$, which further increases the trap density and, hence, has a negative impact on the transfer characteristics. ${ }^{9}$ Therefore, it has been suggested that replacing $\mathrm{SiO}_{2}$ with a high-k dielectric may result in better performance. ${ }^{8,34}$

We also tested devices with a $75 \mathrm{~nm}$ thick $\mathrm{ALD} \mathrm{Al}_{2} \mathrm{O}_{3}$ gate oxide, and observed switching in the devices with a decreased $\mathrm{SS}\left(7.5 \mathrm{~V} \mathrm{dec}^{-1}\right)$ and a $\mathrm{V}_{\mathrm{TH}}$ of $10.6 \mathrm{~V}$ (See Fig. S2), indeed indicating a reduction in the trap states at the dielectric/semiconductor interface. However, in this case the $\mathrm{Al}_{2} \mathrm{O}_{3}$ gate oxide had a lower breakdown voltage than the $100 \mathrm{~nm} \mathrm{SiO}_{2}$, which meant that the channel was not yet fully depleted when the gate modulation was lost, limiting both the $\mathrm{I}_{\text {on }} / \mathrm{I}_{\text {off }}$ ratio and the mobility.

To investigate the effect of annealing on the $\mathrm{Al}_{2} \mathrm{O}_{3} / \mathrm{Cu}_{2} \mathrm{O}$ stack in detail, a high-temperature GIXRD measurement was performed. $10 \mathrm{~nm} \mathrm{Al}_{2} \mathrm{O}_{3}$ was deposited on a $40 \mathrm{~nm} \mathrm{Cu}_{2} \mathrm{O}$ sample and the diffraction patterns were collected at $150-600{ }^{\circ} \mathrm{C}$ in 20 mbar $_{2}$ (Fig. 4). It was observed that at $250{ }^{\circ} \mathrm{C}$ the (111) and (200) reflections shift towards larger $2 \vartheta$ angles, indicating a decrease in the unit-cell parameters, possibly due to stress relaxation when the annealing temperature exceeds the deposition temperature. As seen in the samples annealed 
earlier, signs of metallic $\mathrm{Cu}$ appeared also in the passivated sample. These changes, seen as reflections at ca. $43^{\circ}$ and $50.5^{\circ}$, take place just above $300{ }^{\circ} \mathrm{C}$. At $475^{\circ} \mathrm{C}$ the $\mathrm{Cu}$ reflections disappear and features corresponding to formation of $\mathrm{CuO}$ become visible. These changes in the film structure upon annealing could explain the observed narrow annealing temperature window for optimal TFT performance.

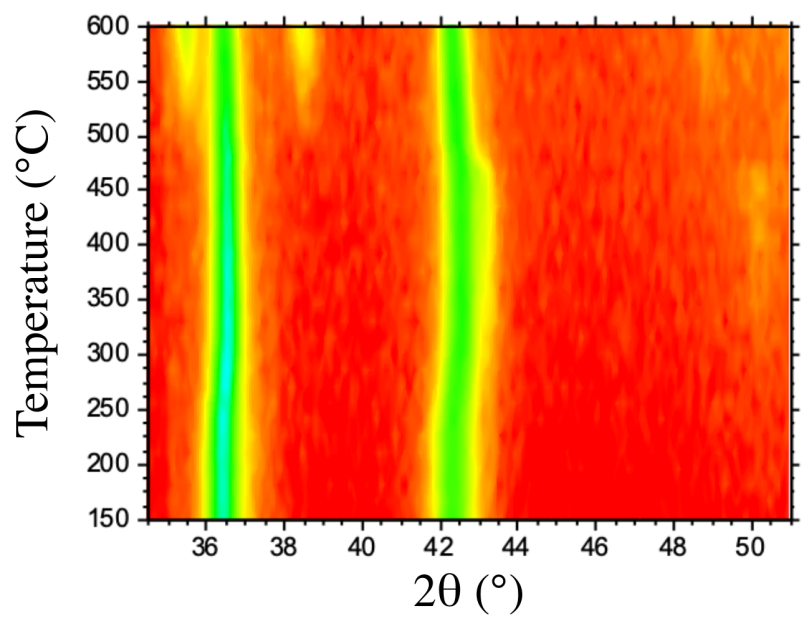

Figure 4: 2D high-temperature GIXRD pattern of the $10 \mathrm{~nm} \mathrm{Al}_{2} \mathrm{O}_{3} / 40 \mathrm{~nm} \mathrm{Cu}_{2} \mathrm{O}$ stack annealed to $150-600{ }^{\circ} \mathrm{C}$ in 20 mbar $\mathrm{N}_{2}$. High intensity lines correspond to the $\mathrm{Cu}_{2} \mathrm{O}$ (111) and (200) reflections. The intensity is plotted in logscale.

Moreover, when annealed under similar conditions, a $\mathrm{Cu}_{2} \mathrm{O}$ film without the $\mathrm{Al}_{2} \mathrm{O}_{3}$ layer undergoes oxidation to $\mathrm{CuO}$ already at $300{ }^{\circ} \mathrm{C}$ (Fig. S3), showing the importance of the $\mathrm{Al}_{2} \mathrm{O}_{3}$ layer to the phase-stability of the films during annealing. This behaviour of both the bare ALD $\mathrm{Cu}_{2} \mathrm{O}$ and the $\mathrm{Al}_{2} \mathrm{O}_{3} \mathrm{Cu}_{2} \mathrm{O}$ film stack differ from what has been shown for $\mathrm{Cu}_{2} \mathrm{O}$ films and devices fabricated by physical deposition methods such as PLD and sputtering. There a high temperature deposition or annealing at $500-800{ }^{\circ} \mathrm{C}$, both in vacuum and inert gas atmosphere have shown to improve the device performance significantly by reduction of the $\mathrm{CuO}$ phases on the grain boundaries and increase in the $\mathrm{Cu}_{2} \mathrm{O}$ crystallite and grain sizes, while the $\mathrm{Cu}_{2} \mathrm{O}$ phase remains stable. ${ }^{3,8,11,26,35,36}$ Though the film thickness may have an effect on the film behaviour during the annealing, it does not fully explain the observed differences between PVD and ALD deposited $\mathrm{Cu}_{2} \mathrm{O}$. One explanation is that the grain 
boundaries of the nanocrystalline $\mathrm{ALD} \mathrm{Cu}_{2} \mathrm{O}$ contain a higher density of hydroxyl groups, which then accelerate the film reduction, despite the presence of the passivation layer, and the partial oxidation into $\mathrm{CuO}$ is later initiated by the oxygen diffusion from both the $\mathrm{Al}_{2} \mathrm{O}_{3}$ layer as well as the $\mathrm{SiO}_{2}$ gate oxide. However, this remains inconclusive.

\section{$\mathrm{Al}_{2} \mathrm{O}_{3} / \mathrm{Cu}_{2} \mathrm{O}$ interface characterisation}

Our results and the previous studies on the passivation of TFTs with oxide semiconductor channels show that quality of the interface between the channel oxide and the passivation layer can have a significant impact on the device performance. Especially, in the case of passivation by chemical routes, such as ALD, it can be assumed that the interface is further modified by the surface chemistry taking place during the layer deposition. It has been shown that exposure to certain ALD metal precursors, namely alkyl compounds, can reduce a surface oxide layer if the reactions are energetically favourable, ${ }^{37-39}$ and this is also routinely utilized e.g. in so-called "self-cleaning" process of III-V semiconductor materials. ${ }^{40}$ In the case of copper oxide surfaces, for surface reactions of diethylzinc, commonly used as a precursor for $\mathrm{ALD} \mathrm{ZnO}$, the Gibbs free energies for reduction reactions of $\mathrm{Cu}_{2} \mathrm{O}$ surface into metallic $\mathrm{Cu}$ are $\Delta \mathrm{G}_{\mathrm{r}}=(-300)-(-200) \mathrm{kJ} \mathrm{mol}^{-1}(\mathrm{~T}=373 \mathrm{~K}) .{ }^{38}$ The reactions between TMA and $\mathrm{Cu}_{2} \mathrm{O}$ can be assumed to be even more favourable due to higher reactivity of the TMA. The reduction of oxidized $\mathrm{Cu}$ surface during the first $\mathrm{Al}_{2} \mathrm{O}_{3}$ cycles has been verified both numerically and experimentally. ${ }^{39,41}$

Gharachorlou et al. investigated the TMA and hydroxyl-free copper surface reactions and presented the mechanism where the $\mathrm{Cu}_{2} \mathrm{O}$ surface is reduced by the highly exothermic stepwise dissociative adsorption reactions of the TMA on the surface. This leads to the consumption of the surface oxygen atoms by the $\mathrm{Al}$ to form $\mathrm{CuAlO}_{2}$ and the remaining $\mathrm{Cu}$

to be in the reduced $\mathrm{Cu}^{0}$ state during the first $\mathrm{Al}_{2} \mathrm{O}_{3}$ cycles. This results in island-type growth of $\mathrm{CuAlO}_{2}$ followed by $\mathrm{Al}_{2} \mathrm{O}_{3}$ film growth when the available $\mathrm{Cu}_{2} \mathrm{O}$ sites have been 
used. Their proposed overall reaction for the $\mathrm{CuAlO}_{2}$ and $\mathrm{Cu}$ formation by TMA is: ${ }^{39}$

$$
2 \mathrm{Cu}_{2} \mathrm{O}+\mathrm{Al}\left(\mathrm{CH}_{3}\right)_{3} \rightarrow \mathrm{CuAlO}_{2}+3 \mathrm{Cu}+2 \mathrm{CH}_{4}(g)+\mathrm{CH}_{a d s} .
$$

Using a process with $\mathrm{H}_{2} \mathrm{O}$ as a reactant leads to surface hydroxyl groups forming during deposition. However, it can be assumed that the mechanism described above is still valid, because it has been calculated that the hydroxyl coverage does not affect the TMA dissociation on the surface, but only on growth efficiency. ${ }^{42}$

The formation of a $\mathrm{CuAlO}_{2}$ interface could be beneficial to TFT performance, because it is a known p-type material with low $\mathrm{V}_{\mathrm{Cu}}$ formation energy. ${ }^{43}$ In order to investigate in detail the reduction of $\mathrm{Cu}_{2} \mathrm{O}$ by TMA, and the formation of the $\mathrm{CuAlO}_{2}$ interface layer, samples were prepared for XPS and TEM. XPS was used to analyse $\mathrm{Cu}_{2} \mathrm{O}$ films with and without the $\mathrm{Al}_{2} \mathrm{O}_{3}$ passivation and subsequent annealing at $300{ }^{\circ} \mathrm{C}$. To minimize the need of $\mathrm{Ar}^{+}$etching to reach the $\mathrm{Al}_{2} \mathrm{O}_{3} / \mathrm{Cu}_{2} \mathrm{O}$ interface, only 20 cycles i.e. ca. $2 \mathrm{~nm}$ of $\mathrm{Al}_{2} \mathrm{O}_{3}$ was deposited on samples for XPS measurements. The XPS of as-deposited $\mathrm{Cu}_{2} \mathrm{O}$ without the $\mathrm{Al}_{2} \mathrm{O}_{3}$ layer confirmed the films to be phase-pure $\mathrm{Cu}_{2} \mathrm{O}$ seen both in the $\mathrm{Cu} 2 \mathrm{p}$ and $\mathrm{Cu}$ LMM spectra, with a minor $\mathrm{CuO}$ content present at the film surface, as well as a high content of hydroxyl groups, as seen in the measured O 1s spectra (See Fig. S4).

The effect of the annealing on the $\mathrm{Cu}_{2} \mathrm{O}$ film was investigated by measuring a sample annealed at $300{ }^{\circ} \mathrm{C}$. No changes to the film composition were observed (Fig. S5). Figure 5 shows the XPS spectra of the $\mathrm{Al}_{2} \mathrm{O}_{3} / \mathrm{Cu}_{2} \mathrm{O}$ films, before and after annealing at $300{ }^{\circ} \mathrm{C}$. As seen in Fig. 5(a) the $\mathrm{Cu} 2 \mathrm{p}$ spectra of the both films show the absence of the $\mathrm{CuO}$ phase. However, the differentiation of between the $\mathrm{Cu}^{+}$and $\mathrm{Cu}^{0}$ states cannot be done from the $\mathrm{Cu} 2 \mathrm{p}$ spectrum. The complementary Cu LMM spectra of the samples in Fig. 5(b) show the significant broadening of the Auger electron peak compared to the $\mathrm{Cu}_{2} \mathrm{O}$ sample without the $\mathrm{Al}_{2} \mathrm{O}_{3}$ layer. This corresponds to the presence of the metallic $\mathrm{Cu}^{0}$ at the $\mathrm{Al}_{2} \mathrm{O}_{3} / \mathrm{Cu}_{2} \mathrm{O}$ interface, confirming the reduction of the $\mathrm{Cu}_{2} \mathrm{O}$ due to TMA exposure. ${ }^{44} \mathrm{This} \mathrm{Cu}^{0}$ can remain 
metallic even after the subsequent pulsing of $\mathrm{H}_{2} \mathrm{O}$, as the oxidation reactions into $\mathrm{Cu}_{2} \mathrm{O}$ or $\mathrm{CuO}$ are not thermodynamically favourable (Tab. S1(a) and (b)). However, the oxidation by residual $\mathrm{O}_{2}$ in the deposition reactor is possible (Tab. S1(b) and (c)). Furthermore, because the TMA adsorption and dissociation is not favourable on $\mathrm{Cu}$ sites, it is feasible to assume that the metallic $\mathrm{Cu}^{0}$ is not consumed to form $\mathrm{CuAlO}_{2}$ or oxidised to copper oxides but will remain at the interface, as shown by our results.

The O 1s spectra were also recorded from both samples. The deconvoluted spectra in Fig. 5(c) and (d) show the oxygen in lattice $\mathrm{Cu}_{2} \mathrm{O}$ at $530.2 \mathrm{eV}$, a minor $\mathrm{CuO}$ contribution at $529.8 \mathrm{eV}$, and $\mathrm{Al}_{2} \mathrm{O}_{3}$ bound oxygen at $531.6 \mathrm{eV}$, as well as the presence of high hydroxyl concentration $(\sim 532 \mathrm{eV}) .{ }^{45}$ This is contributed by both the persistent surface hydroxyl groups on the $\mathrm{Cu}_{2} \mathrm{O}$ as well as the remaining $-\mathrm{OH}$ species in the $\mathrm{Al}_{2} \mathrm{O}_{3}$ from the TMA + water process at relatively low deposition temperature of $150{ }^{\circ} \mathrm{C}$. There is a small difference in the $\mathrm{O}$ 1s spectra of the as-deposited and annealed samples, namely in the $\mathrm{Al}_{2} \mathrm{O}_{3}$ related $\mathrm{O}$ content, which may indicate a partial diffusion of the $\mathrm{Al}$ into the $\mathrm{Cu}_{2} \mathrm{O}$ film or a densification of the film upon annealing, which would lead to a slightly different etching rate during the Ar ion sputter cleaning.

However, the measured ex-situ XPS data can not be reliably used to confirm the presence of the $\mathrm{CuAlO}_{2}$ phase at the $\mathrm{Al}_{2} \mathrm{O}_{3} / \mathrm{Cu}_{2} \mathrm{O}$ interface, as the related changes are too subtle to be distinguished from the $\mathrm{Al}_{2} \mathrm{O}_{3}$ and $\mathrm{Cu}_{2} \mathrm{O}$ signals within the probed volume. Moreover, we measured the valence spectra of the annealed $\mathrm{Cu}_{2} \mathrm{O}$ and $\mathrm{Al}_{2} \mathrm{O}_{3} / \mathrm{Cu}_{2} \mathrm{O}$ samples. Deuermeier et al. reported a shift in the binding energy of a $\mathrm{Cu}_{2} \mathrm{O}$ during the $\mathrm{ALD}$ of $\mathrm{Al}_{2} \mathrm{O}_{3}$. In their in situ XPS experiments on $\mathrm{ALD} \mathrm{Al}_{2} \mathrm{O}_{3}$ growth on sputtered $\mathrm{Cu}_{2} \mathrm{O}$ surface the position of the valence band edge $\left(E_{F}-E_{V B}\right)$ of the $\mathrm{Cu}_{2} \mathrm{O}$ increased from original $0.4 \mathrm{eV}$ to $0.6 \mathrm{eV}$ after the first $\mathrm{Al}_{2} \mathrm{O}_{3}$ ALD cycle indicating a formation of $\mathrm{Cu} / \mathrm{Cu}_{2} \mathrm{O}$ Schottky junction. ${ }^{41}$ Though our core level LMM spectrum showed the formation of the $\mathrm{Cu}$, similar indication of a Schottky junction formation was not observed in the valence spectra and $0.9 \mathrm{eV} E_{F}-E_{V B}$ was measured for both the original $\mathrm{Cu}_{2} \mathrm{O}$ as well as for the $\mathrm{Al}_{2} \mathrm{O}_{3} / \mathrm{Cu}_{2} \mathrm{O}$ interface (See Fig. 
S6). However, this does not exclude the potential Fermi level pinning at the interface due to the reasons explained above.

To obtain more evidence on the proposed $\mathrm{CuAlO}_{2}$ interface layer formation, a sample with $10 \mathrm{~nm} \mathrm{Al}_{2} \mathrm{O}_{3}$ deposited on $\mathrm{Cu}_{2} \mathrm{O}$, annealed at $300{ }^{\circ} \mathrm{C}$, was imaged with TEM. The TEM and STEM coupled with EDS elemental mapping was recorded from the film interface (Fig. 6) from the very thin edge of the TEM foil. Figure 6(a) shows a low magnification image confirming the film stack, with a $\mathrm{Cu}_{2} \mathrm{O}$ film sandwiched between two $10 \mathrm{~nm} \mathrm{Al}_{2} \mathrm{O}_{3}$ films on $\mathrm{SiO}_{2} / \mathrm{Si}$. In Fig. 6(b) the enlarged TEM shows the polycrystalline $\mathrm{Cu}_{2} \mathrm{O}$ and with the conformal, amorphous $\mathrm{Al}_{2} \mathrm{O}_{3}$ on top. The STEM image (6c) along with the EDS mapping results $(6 \mathrm{~d})$ at the interface region reveals a $1-2 \mathrm{~nm}$ region at the interface with a mixed $\mathrm{Al}$ and $\mathrm{Cu}$ oxide composition (Fig. 6(d)). Though the actual composition of this region cannot be reliably determined from the STEM-EDS data, it is in qualitative agreement with the observations by Gharachorlou et al. of a formation of a $\mathrm{CuAlO}_{2}$ layer during the first $\mathrm{Al}_{2} \mathrm{O}_{3}$ cycles according to Eq. 1.

The partial reduction of the film surface by the TMA can explain the decreased $\mathrm{I}_{\mathrm{DS}}$ over the whole gate voltage range when the $\mathrm{Al}_{2} \mathrm{O}_{3}$ passivation layer is applied, as presented in Fig. 2. It has been shown that the inevitable formation of thin $\mathrm{CuO}$ layer on the $\mathrm{Cu}_{2} \mathrm{O}$ grain surfaces under ambient conditions increases the conductivity of $\mathrm{Cu}_{2} \mathrm{O}$ films, which can affect the device performance. ${ }^{27}$ The surface $\mathrm{Cu}_{2} \mathrm{O}$ reduction by TMA thus decreases the film conductivity. However, this reduction mechanism and formation of the interfacial $\mathrm{CuAlO}_{2}$ do not fully explain the significant improvement in the TFT performance by the decrease in the device off-state current. We tested the effect of the $\mathrm{Al}_{2} \mathrm{O}_{3}$ film thickness on the TFT transfer characteristics and observed that when the nominal $\mathrm{Al}_{2} \mathrm{O}_{3}$ thickness was $2-5 \mathrm{~nm}$ the device performance was similar to TFTs without the $\mathrm{Al}_{2} \mathrm{O}_{3}$ passivation and the improvement in the TFT transfer characteristics was detected only with a thicker, $10 \mathrm{~nm} \mathrm{Al}_{2} \mathrm{O}_{3}$ layers (See Fig. S7). This indicates that the formation of the interface layer by the TMA exposure during the first couple of tens of deposition cycles is not sufficient in improving the device 

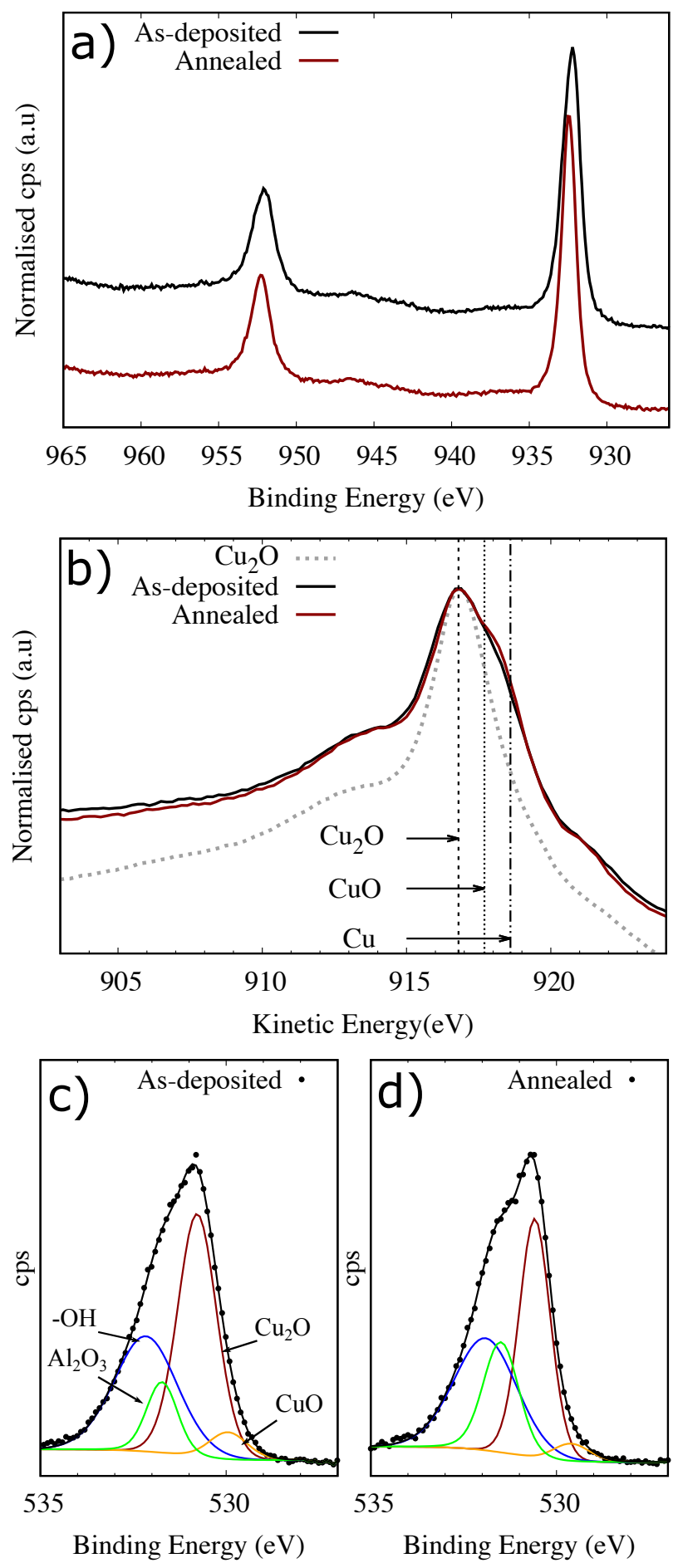

Figure 5: XPS spectra of the $\mathrm{Al}_{2} \mathrm{O}_{3} / \mathrm{Cu}_{2} \mathrm{O}$ interface region, measured after $90 \mathrm{~s} 0.5 \mathrm{keV} \mathrm{Ar} \mathrm{Ar}^{+}$ sputtering, (a) $\mathrm{Cu} 2 \mathrm{p}$ of the as-deposited (black) and annealed (dark red) samples. (b) $\mathrm{Cu}$ LMM Auger electron spectra, corresponding spectrum of a $\mathrm{Cu}_{2} \mathrm{O}$ film without the $\mathrm{Al}_{2} \mathrm{O}_{3}$ passivation layer shown by dashed grey line as a reference. The $\mathrm{O} 1 \mathrm{~s}$ spectra of the (c) asdeposited and (d) annealed sample. The deconvoluted peaks correspond to oxygen in $\mathrm{Cu}_{2} \mathrm{O}$ (dark red), $\mathrm{CuO}$ (orange), hydroxyl -OH (blue), and $\mathrm{Al}_{2} \mathrm{O}_{3}$ (green). 


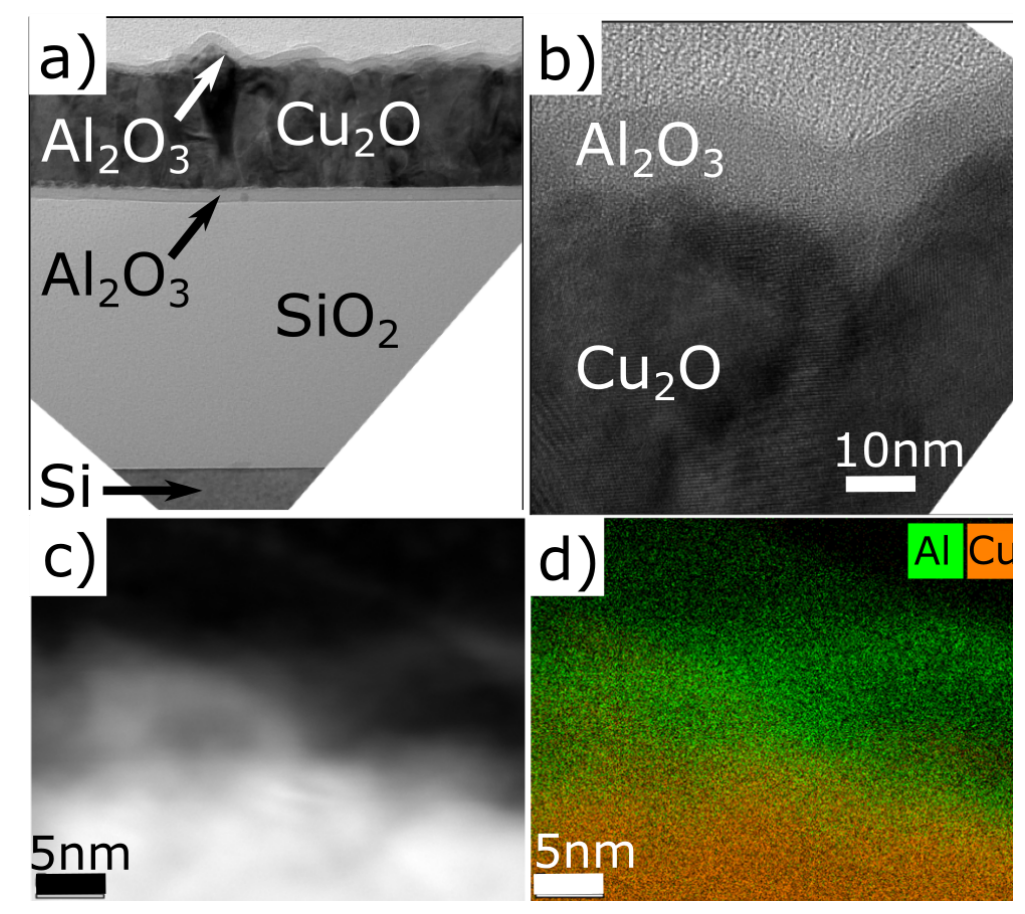

Figure 6: Transmission electron microscopy (TEM) micrographs (a)-(b) of a $\mathrm{Cu}_{2} \mathrm{O}$ thin film sample with $10 \mathrm{~nm} \mathrm{Al}_{2} \mathrm{O}_{3}$ passivation layer, annealed in 1.5 mbar $\mathrm{N}_{2}$ for $10 \mathrm{~min}$. (c) Scanning transmission electron microscope (STEM) image and (d) the corresponding TEMEDS mapping of $\mathrm{Al}$ and $\mathrm{Cu}$ at the sample interface.

performance, but thicker coverage with the $\mathrm{Al}_{2} \mathrm{O}_{3}$ layer is required. The thicker layer can act as an enhanced barrier against oxygen and moisture, but it is unlikely that this is the sole reason for the significant TFT performance improvement. Therefore, the key to the improved characteristics are likely in the properties of the $\mathrm{ALD} \mathrm{Al}_{2} \mathrm{O}_{3}$ film itself.

A plausible reason for the observed behaviour is the high negative fixed charge density $\left(Q_{\mathrm{f}}=10^{-13} \mathrm{~cm}^{-2}\right)$ of the $\mathrm{ALD} \mathrm{Al}_{2} \mathrm{O}_{3}$, which has traditionally been utilised in c-Si solar cells where it reduces the recombination losses on the Si surface via surface defect density reduction and by field-effect passivation. The field-effect passivation is based on the reduction of electron or hole concentrations on the surface/interface by the means of an intrinsic internal electric field. ${ }^{46,47}$ In our measured TFT data the impact of the field-effect passivation is indicated by the negative shift in the $\mathrm{V}_{\mathrm{TH}}$ and the reduction in the $\mathrm{I}_{\mathrm{off}}$. It has previously been reported by Han et al. that the high off-state current in the $\mathrm{Cu}_{2} \mathrm{O}$ TFTs is due to accumulation of minority charge carriers (electrons) at positive gate voltage regime. ${ }^{48} \mathrm{We}$ 
also measured the capacitance of the as-deposited and passivated p-channels (See Fig. S8). The results qualitatively show the enhanced hole accumulation in the channel, especially at low frequencies, which supports the hypothesis of the reduced electron accumulation. The application of the field-effect passivation by $\mathrm{ALD} \mathrm{Al}_{2} \mathrm{O}_{3}$ on the $\mathrm{Cu}_{2} \mathrm{O}$ channel and subsequent annealing can be an effective way in reducing the accumulation of electrons via electrostatic shielding, which leads to the orders of magnitude lower off-state current and, hence, improves the performance of TFTs with $\mathrm{Cu}_{2} \mathrm{O}$ p-channels.

\section{Conclusions}

p-Type thin film transistors with ALD grown phase pure polycrystalline $\mathrm{Cu}_{2} \mathrm{O}$ channel layer were fabricated. The TFTs with as-deposited films showed only limited switching performance, due to the unoptimised film properties and processing parameters, but the characteristics were improved by depositing an $10 \mathrm{~nm} \mathrm{ALD} \mathrm{Al}_{2} \mathrm{O}_{3}$ passivation layer on the $\mathrm{Cu}_{2} \mathrm{O}$ channel and by subsequent annealing at $300{ }^{\circ} \mathrm{C}$ in low vacuum. The analysis of the transfer characteristics indicates that the improvement is due to the reduced number of trap states at the channel. The detailed investigation of the $\mathrm{Al}_{2} \mathrm{O}_{3} / \mathrm{Cu}_{2} \mathrm{O}$ interface by XPS and TEM showed a partial reduction of the $\mathrm{Cu}_{2} \mathrm{O}$ and possible formation of a 1-2 nm thick $\mathrm{CuAlO}_{2}$ layer. This presents an example of the importance of understanding the surface reactions and interface modification during the ALD growth on multilayer stacks, as it can significantly impact the performance of thin film devices.Here, the reduced copper oxide surface and the formation of p-type $\mathrm{CuAlO}_{2}$ layer with a low $\mathrm{Cu}$ vacancy formation energy can be beneficial to the device operation, but cannot solely explain the better performance of the $\mathrm{Al}_{2} \mathrm{O}_{3}$ passivated TFTs. Hence, we conclude that the main benefit of the $\mathrm{Al}_{2} \mathrm{O}_{3}$ passivation comes from its high negative fixed charge density that reduces the accumulation of electrons in the $\mathrm{Cu}_{2} \mathrm{O}$ channel when positive gate voltage is applied and, thus, reduces the $\mathrm{I}_{\text {off }}$ of the devices. While the field-effect passivation may not be applicable to tradition nanoscale 
Si-based CMOS devices, as it influences the $\mathrm{V}_{\text {th }}$ and the transport of charge carriers in ways that can be detrimental to the circuit operation, it can be an useful tool in the development of alternative approaches that utilise p-type oxide semiconductors with moderate charge carrier density.

\section{Experimental}

The $\mathrm{Cu}_{2} \mathrm{O}$ films were grown on $5 \mathrm{~cm} \times 5 \mathrm{~cm}$ substrates of thermally grown $\mathrm{SiO}_{2}$ on p-Si (resistivity $0.001 \Omega \mathrm{cm}$, Si-Mat) by atomic layer deposition at $200^{\circ} \mathrm{C}$ in an ASM F-120 reactor. Copper(II) acetate $\mathrm{Cu}(\mathrm{OAc})_{2}$ with source temperature of $185^{\circ} \mathrm{C}$, and water vapor were used as precursors. Each $\mathrm{Cu}_{2} \mathrm{O}$ ALD cycle consisted of $2 \mathrm{~s} \mathrm{Cu}(\mathrm{OAc})_{2}$ pulse / 2 s purge / $1.5 \mathrm{~s} \mathrm{H}_{2} \mathrm{O}$ pulse / 1.5 s purge, which resulted a growth per cycle of $0.011 \mathrm{~nm}$. A fluorine-free precursor was chosen because residual fluorine impurities can affect the electrical properties of the films, F being a known n-type dopant, and, additionally lead to poor adhesion of the films due to the accumulation of the fluorine into the interfaces. ${ }^{49}$ Details of the growth chemistry and materials characterisation are published by Iivonen et al. in Ref. ${ }^{23}$ No further optimisation of the $\mathrm{Cu}_{2} \mathrm{O}$ film processing or thickness was done regarding the device operation. Bottom gate TFT structures, with the Si substrate acting as a common gate and thermally grown $100 \mathrm{~nm}$ thick $\mathrm{SiO}_{2}$ as a gate dielectric, were fabricated with a standard photolithography and nanofabrication methods to test the performance of the $\mathrm{Cu}_{2} \mathrm{O}$ films. The $40 \mathrm{~nm} \mathrm{Cu}_{2} \mathrm{O}$ films were patterned by wet etching using diluted (0.025 M aq.) HCl, and $100 \mathrm{~nm}$ thick $\mathrm{Au}$ source and drain electrodes were deposited by thermal evaporation (Edwards Coating System E306A), with a base pressure of $10^{-6}$ mbar. Au was chosen as the electrode material to ensure an ohmic contact was made between the film and the electrodes. That is because of the high work function (WF) of $\mathrm{Au} 5.1-5.4 \mathrm{eV}^{50}$ that matches the ca. 4.9-5.0 eV WF of $\mathrm{Cu}_{2} \mathrm{O},{ }^{27,51}$ as well as its high standard reduction potential, which avoids electrode oxidation during annealing. After electrode patterning, the device samples were diced, and the $\mathrm{Cu}_{2} \mathrm{O}$ channel 
was passivated by a $10 \mathrm{~nm} \mathrm{Al}_{2} \mathrm{O}_{3}$ film grown by ALD (Cambridge Nanotech (Veeco) Savannah $\mathrm{S} 100)$ at $150{ }^{\circ} \mathrm{C}$ with trimethylaluminium (TMA, Sigma Aldrich) and water vapour. Finally, the devices were annealed in 1.5 mbar $\mathrm{N}_{2}$ at $200-400{ }^{\circ} \mathrm{C}$ for 10 minutes.

Film thickness was determined with x-ray reflectivity (XRR) using a PANalytical X'Pert Pro MPD diffractometer, which was also used for x-ray diffraction (XRD) measurements. The measurements were performed in the grazing incidence (GIXRD) geometry at an incidence angle of $1^{\circ}$. The same geometry was used with the high-temperature GIXRD measurements, where Anton-Paar HTK1200N furnace was used for sample heating in 20 mbar $\mathrm{N}_{2}\left(\mathrm{~N}_{2}\right.$ flow $\left.40 \mathrm{sccm}\right)$ and data were collected at $150-600{ }^{\circ} \mathrm{C}$ with $15{ }^{\circ} \mathrm{C}$ intervals. Atomic force microscopy (AFM) images were taken with Bruker Multimode 8. The electrical properties of the $\mathrm{Cu}_{2} \mathrm{O}$ films were characterised by Hall-effect measurements using van der Pauw configuration with a magnetic field of $0.2 \mathrm{~T}$ at room temperature (MMR Technologies Hall System). Thin film transistors were measured using a Cascade probe station and Agilent B1500A semiconductor device parameter analyser. The electrical characterisations were performed in dark to suppress the film photoconductivity. In the interface examinations Escalab (Thermo Fisher Scientific) x-ray microprobe was used for x-ray photoelectron spectroscopy (XPS), and the results were analysed using CasaXPS processing software. Transmission electron microscopy (TEM) imaging was done using FEI TALOS T200X operated at $200 \mathrm{kV}$ with EDS for elemental mapping.

\section{Acknowledgement}

M.N., T.N.M, A.J.F, and J.L. M.-D. acknowledge funding from the EPSRC grant EP/P027032/1 and PragmatIC Ltd. J.L.M.-D .acknowledges funding from the Royal Academy of Engineering grant CIET 1819_24. R.L.Z.H. thanks the Royal Academy of Engineering for support via the Research Fellowships scheme (no. RF/201718/1701). Han W. and H.W. acknowledge the support from the U.S. National Science Foundation (NSF, DMR- 2016453) for the TEM 
work at Purdue University.

\section{Supporting Information Available}

More detailed information and experimental data on Hall mobility, thin film transistor characteristics, high-temperature GIXRD, X-ray photoelectron spectroscopy, and $\mathrm{Cu}$ and $\mathrm{Cu}_{2} \mathrm{O}$ oxidation are available in Supporting Information.

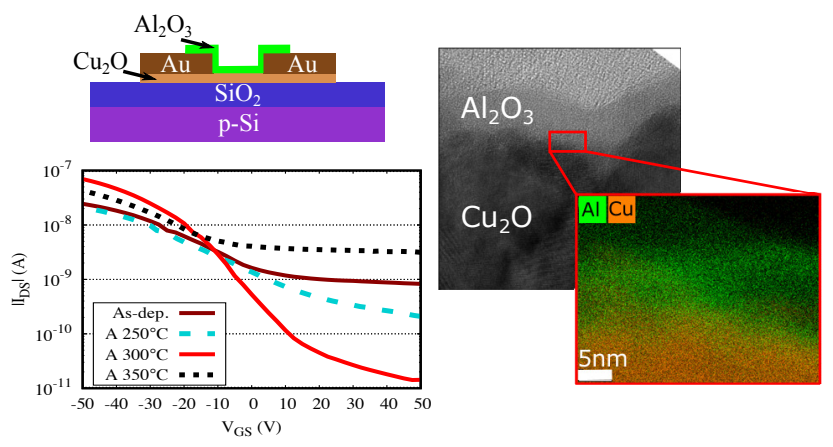

Figure 7: For Table of Contents Only

\section{References}

(1) Hosono, H. In Handbook of Visual Display Technology; Chen, J., Cranton, W., Fihn, M., Eds.; Springer Berlin Heidelberg: Berlin, Heidelberg, 2012; pp 729-749.

(2) Sheng, J.; Hong, T.; Lee, H.-M.; Kim, K.; Sasase, M.; Kim, J.; Hosono, H.; Park, J.-S. Amorphous IGZO TFT with High Mobility of $\sim 70 \mathrm{~cm} 2 /(\mathrm{V} s)$ via Vertical Dimension Control Using PEALD. ACS Appl. Mater. Inter. 2019, 11, 40300-40309.

(3) Wang, Z.; Nayak, P. K.; Caraveo-Frescas, J. A.; Alshareef, H. N. Recent Developments in p-Type Oxide Semiconductor Materials and Devices. Adv. Mater. 2016, 28, 38313892.

(4) Nolan, M.; Elliott, S. D. The p-Type Conduction Mechanism in $\mathrm{Cu}_{2} \mathrm{O}$ : a First Principles Study. Phys. Chem. Chem. Phys. 2006, 8, 5350-5358. 
(5) Al-Jawhari, H. A Review of Recent Advances in Transparent p-Type $\mathrm{Cu}_{2} \mathrm{O}$-Based Thin Film Transistors. Mat. Sci. Semicon. Proc. 2015, 40, $241-252$.

(6) Zhang, J., N.and Sun; Gong, H. Transparent p-Type Semiconductors: Copper-Based Oxides and Oxychalcogenides. Coatings 2019, 9, 137.

(7) Matsuzaki, K.; Nomura, K.; Yanagi, H.; Kamiya, T.; Hirano, M.; Hosono, H. Epitaxial Growth of High Mobility $\mathrm{Cu}_{2} \mathrm{O}$ Thin Films and Application to p-Channel Thin Film Transistor. Appl. Phys. Lett. 2008, 93, 202107.

(8) Zou, X.; Fang, G.; Yuan, L.; Li, M.; Guan, W.; Zhao, X. Top-Gate Low-Threshold Voltage $p-\mathrm{Cu}_{2} \mathrm{O}$ Thin-Film Transistor Grown on $\mathrm{SiO}_{2} / \mathrm{Si}$ Substrate Using a High- $\kappa$ HfON Gate Dielectric. IEEE Electron Dev. Lett. 2010, 31, 827-829.

(9) Ran, F.-Y.; Taniguti, M.; Hosono, H.; Kamiya, T. Analyses of Surface and Interfacial Layers in Polycrystalline $\mathrm{Cu}_{2} \mathrm{O}$ Thin-Film Transistors. J. Display Technol. 2015, 11, $720-724$.

(10) Fortunato, E.; Figueiredo, V.; Barquinha, P.; Elamurugu, E.; Barros, R.; Gonçalves, G.; Park, S.-H. K.; Hwang, C.-S.; Martins, R. Thin-film Transistors Based on p-Type $\mathrm{Cu}_{2} \mathrm{O}$ Thin Films Produced at Room Temperature. Appl. Phys. Lett. 2010, 96, 192102.

(11) Jeong, C.-Y.; Sohn, J.; Song, S.-H.; Cho, I.-T.; Lee, J.-H.; Cho, E.-S.; Kwon, H.-I. Investigation of the Charge Transport Mechanism and Subgap Density of States in p-Type $\mathrm{Cu}_{2} \mathrm{O}$ Thin-Film Transistors. Appl. Phys. Lett. 2013, 102, 082103.

(12) Han, S.; Niang, K. M.; Rughoobur, G.; Flewitt, A. J. Effects of Post-Deposition Vacuum Annealing on Film Characteristics of p-Type $\mathrm{Cu}_{2} \mathrm{O}$ and Its Impact on Thin Film Transistor Characteristics. Appl. Phys. Lett. 2016, 109, 173502.

(13) Kim, S. Y.; Ahn, C. H.; Lee, J. H.; Kwon, Y. H.; Hwang, S.; Lee, J. Y.; Cho, H. K. 
p-Channel Oxide Thin Film Transistors Using Solution-Processed Copper Oxide. ACS Appl. Mater. Inter. 2013, 5, 2417-2421.

(14) Jang, J.; Chung, S.; Kang, H.; Subramanian, V. p-Type $\mathrm{CuO}$ and $\mathrm{Cu}_{2} \mathrm{O}$ Transistors Derived from a Sol-Gel Copper (II) Acetate Monohydrate precursor. Thin Solid Films 2016, 600, $157-161$.

(15) Musselman, K. P.; Marin, A.; Schmidt-Mende, L.; MacManus-Driscoll, J. L. Incompatible Length Scales in Nanostructured $\mathrm{Cu}_{2} \mathrm{O}$ Solar Cells. Advanced Functional Materials 2012, 22, 2202-2208.

(16) Baby, T. T.; Garlapati, S. K.; Dehm, S.; Häming, M.; Kruk, R.; Hahn, H.; Dasgupta, S. A General Route toward Complete Room Temperature Processing of Printed and High Performance Oxide Electronics. ACS Nano 2015, 9, 3075-3083.

(17) Cho, M. H.; Seol, H.; Song, A.; Choi, S.; Song, Y.; Yun, P. S.; Chung, K.; Bae, J. U.; Park, K.; Jeong, J. K. Comparative Study on Performance of IGZO Transistors With Sputtered and Atomic Layer Deposited Channel Layer. IEEE T. Electron Dev. 2019, $66,1783-1788$.

(18) Sheng, J.; Lee, J.-H.; Choi, W.-H.; Hong, T.; Kim, M.; Park, J.-S. Review Article: Atomic Layer Deposition for Oxide Semiconductor Thin Film Transistors: Advances in Research and Development. J. Vac. Sci. Technol. A 2018, 36, 060801.

(19) Sheng, J.; Han, K.-L.; Hong, T.; Choi, W.-H.; Park, J.-S. Review of Recent Progresses on Flexible Oxide Semiconductor Thin Film Transistors Based on Atomic Layer Deposition Processes. J. Semicond. 2018, 39, 011008.

(20) Zardetto, V.; Williams, B. L.; Perrotta, A.; Di Giacomo, F.; Verheijen, M. A.; Andriessen, R.; Kessels, W. M. M.; Creatore, M. Atomic Layer Deposition for Perovskite Solar Cells: Research status, Opportunities and Challenges. Sustain. Energy Fuels 2017, 1, 30-55. 
(21) Maeng, W.; Lee, S.-H.; Kwon, J.-D.; Park, J.; Park, J.-S. Atomic Layer Deposited pType Copper Oxide Thin Films and the Associated Thin Film Transistor Properties. Ceram. Int. 2016, 42, $5517-5522$.

(22) Kim, S. H.; Baek, I.-H.; Kim, D. H.; Pyeon, J. J.; Chung, T.-M.; Baek, S.-H.; Kim, J.-S.; Han, J. H.; Kim, S. K. Fabrication of High-Performance p-Type Thin Film Transistors Using Atomic-Layer-Deposited SnO Films. J. Mater. Chem. C 2017, 5, 3139-3145.

(23) Iivonen, T.; Heikkilä, M. J.; Popov, G.; Nieminen, H.-E.; Kaipio, M.; Kemell, M.; Mattinen, M.; Meinander, K.; Mizohata, K.; Räisänen, J.; Ritala, M.; Leskelä, M. Atomic Layer Deposition of Photoconductive $\mathrm{Cu}_{2} \mathrm{O}$ Thin Films. ACS Omega 2019, 4, $11205-11214$.

(24) Muñoz-Rojas, D.; Jordan, M.; Yeoh, C.; Marin, A. T.; Kursumovic, A.; Dunlop, L. A.; Iza, D. C.; Chen, A.; Wang, H.; MacManus Driscoll, J. L. Growth of 5 cm2V-1s-1 Mobility, p-Type Copper(I) Oxide $\left(\mathrm{Cu}_{2} \mathrm{O}\right)$ Films by Fast Atmospheric Atomic Layer Deposition (AALD) at $225^{\circ} \mathrm{C}$ and Below. AIP Adv. 2012, 2, 042179.

(25) Chen, W.-C.; Hsu, P.-C.; Chien, C.-W.; Chang, K.-M.; Hsu, C.-J.; Chang, C.-H.; Lee, W.-K.; Chou, W.-F.; Hsieh, H.-H.; Wu, C.-C. Room-Temperature-Processed Flexible n-InGaZnO/p- $\mathrm{Cu}_{2} \mathrm{O}$ Heterojunction Diodes and High-Frequency Diode Rectifiers. J. Phys. D: Appl. Phys. 2014, 47, 365101.

(26) Han, S.; Flewitt, A. J. Analysis of the Conduction Mechanism and Copper Vacancy Density in p-Type $\mathrm{Cu}_{2} \mathrm{O}$ Thin Films. Sci. Rep. 2017, 7, 5766 .

(27) Deuermeier, J.; Liu, H.; Rapenne, L.; Calmeiro, T.; Renou, G.; Martins, R.; MuñozRojas, D.; Fortunato, E. Visualization of Nanocrystalline $\mathrm{CuO}$ in the Grain Boundaries of $\mathrm{Cu}_{2} \mathrm{O}$ Thin Films and Effect on Band Bending and Film Resistivity. APL Materials 2018, 6, 096103. 
(28) Chen, Y.-C.; Chang, T.-C.; Li, H.-W.; Chen, S.-C.; Lu, J.; Chung, W.-F.; Tai, Y.-H.; Tseng, T.-Y. Bias-induced Oxygen Adsorption in Zinc Tin Oxide Thin Film Transistors Under Dynamic Stress. Appl. Phys. Lett. 2010, 96, 262104.

(29) Hu, S.; Ning, H.; Lu, K.; Fang, Z.; Tao, R.; Yao, R.; Zou, J.; Xu, M.; Wang, L.; Peng, J. Effect of $\mathrm{Al}_{2} \mathrm{O}_{3}$ Passivation Layer and $\mathrm{Cu}$ Electrodes on High Mobility of Amorphous IZO TFT. IEEE J. Electron Devi. 2018, 6, 733-737.

(30) Hong, S.; Park, S. P.; Kim, Y.-g.; Kang, B. H.; Na, J. W.; Kim, H. J. Low-Temperature Fabrication of an $\mathrm{HfO}_{2}$ Passivation Layer for Amorphous Indium-Gallium-Zinc Oxide Thin Film Transistors Using a Solution Process. Sci. Rep. 2017, 7, 16265.

(31) Tak, Y. J.; Keene, S. T.; Kang, B. H.; Kim, W.-G.; Kim, S. J.; Salleo, A.; Kim, H. J. Multifunctional, Room-Temperature Processable, Heterogeneous Organic Passivation Layer for Oxide Semiconductor Thin-Film Transistors. ACS Appl. Mater. Inter. 2020, 12, 2615-2624.

(32) Qu, Y.; Yang, J.; Li, Y.; Zhang, J.; Wang, Q.; Song, A.; Xin, Q. Organic and Inorganic Passivation of p-Type SnO Thin-Film Transistors with Different Active Layer Thicknesses. Semicond. Sci. Tech. 2018, 33, 075001.

(33) Yao, Z. Q.; Liu, S. L.; Zhang, L.; He, B.; Kumar, A.; Jiang, X.; Zhang, W. J.; Shao, G. Room Temperature Fabrication of p-Channel $\mathrm{Cu}_{2} \mathrm{O}$ Thin-Film Transistors on Flexible Polyethylene Terephthalate Substrates. Appl. Phys. Lett. 2012, 101, 042114.

(34) Zou, X.; Fang, G.; Wan, J.; He, X.; Wang, H.; Liu, N.; Long, H.; Zhao, X. Improved Subthreshold Swing and Gate-Bias Stressing Stability of p-Type $\mathrm{Cu}_{2} \mathrm{O}$ Thin-Film Transistors Using a $\mathrm{HfO}_{2}$ High- $k$ Gate Dielectric Grown on a $\mathrm{SiO}_{2} / \mathrm{Si}$ Substrate by Pulsed Laser Ablation. IEEE T. Electron Dev. 2011, 58, 2003-2007.

(35) Sohn, J.; Song, S.-H.; Nam, D.-W.; Cho, I.-T.; Cho, E.-S.; Lee, J.-H.; Kwon, H.- 
I. Effects of Vacuum Annealing on the Optical and Electrical Properties of p-Type Copper-Oxide Thin-Film Transistors. Semicond. Sci. Tech. 2012, 28, 015005.

(36) Nam, D.-W.; Cho, I.-T.; Lee, J.-H.; Cho, E.-S.; Sohn, J.; Song, S.-H.; Kwon, H.-I. Active Layer Thickness Effects on the Structural and Electrical Properties of p-Type $\mathrm{Cu}_{2} \mathrm{O}$ Thin-Film Transistors. J. Vac. Sci. Technol. B 2012, 30, 060605.

(37) Lee, S. W.; Liu, Y.; Heo, J.; Gordon, R. G. Creation and Control of Two-Dimensional Electron Gas Using Al-Based Amorphous Oxides/SrTiO 3 Heterostructures Grown by Atomic Layer Deposition. Nano Letters 2012, 12, 4775-4783.

(38) Lee, S. W.; Lee, Y. S.; Heo, J.; Siah, S. C.; Chua, D.; Brandt, R. E.; Kim, S. B.; Mailoa, J. P.; Buonassisi, T.; Gordon, R. G. Improved $\mathrm{Cu}_{2} \mathrm{O}$-Based Solar Cells Using Atomic Layer Deposition to Control the $\mathrm{Cu}$ Oxidation State at the p-n Junction. Adv. Energy Mater. 2014, 4, 1301916.

(39) Gharachorlou, A.; Detwiler, M. D.; Gu, X.-K.; Mayr, L.; Klötzer, B.; Greeley, J.; Reifenberger, R. G.; Delgass, W. N.; Ribeiro, F. H.; Zemlyanov, D. Y. Trimethylaluminum and Oxygen Atomic Layer Deposition on Hydroxyl-Free $\mathrm{Cu}(111)$. ACS Appl. Mater. Inter. 2015, 7, 16428-16439.

(40) Long, R.; McIntyre, P. Surface Preparation and Deposited Gate Oxides for Gallium Nitride Based Metal Oxide Semiconductor Devices. Materials 2012, 5, 1297-1335.

(41) Deuermeier, J.; Bayer, T. J. M.; Yanagi, H.; Kiazadeh, A.; Martins, R.; Klein, A.; Fortunato, E. Substrate Reactivity as the Origin of Fermi Level Pinning at the $\mathrm{Cu}_{2} \mathrm{O} / \mathrm{ALD}$ $\mathrm{Al}_{2} \mathrm{O}_{3}$ Interface. Mater. Res. Express 2016, 3, 046404.

(42) Elliott, S. D.; Greer, J. C. Simulating the Atomic Layer Deposition of Alumina from First Principles. J. Mater. Chem. 2004, 14, 3246-3250. 
(43) Kawazoe, H.; Yasukawa, M.; Hyodo, H.; Kurita, M.; Yanagi, H.; Hosono, H. p-Type Electrical Conduction in Transparent Thin Films of $\mathrm{CuAlO}_{2}$. Nature 1997, 389, 939942.

(44) Biesinger, M. C. Advanced Analysis of Copper X-ray Photoelectron Spectra. Surf. Interface Anal. 2017, 49, 1325-1334.

(45) Biesinger, M. C.; Lau, L. W.; Gerson, A. R.; Smart, R. S. Resolving Surface Chemical States in XPS Analysis of First Row Transition Metals, Oxides and Hydroxides: Sc, Ti, V, Cu and Zn. Appl. Surf. Sci. 2010, 257, $887-898$.

(46) Hoex, B.; Gielis, J. J. H.; van de Sanden, M. C. M.; Kessels, W. M. M. On the cSi Surface Passivation Mechanism by the Negative-Charge-Dielectric $\mathrm{Al}_{2} \mathrm{O}_{3}$. J. Appl. Phys. 2008, 104, 113703.

(47) Dingemans, G.; Kessels, W. M. M. Status and Prospects of $\mathrm{Al}_{2} \mathrm{O}_{3}$-Based Surface Passivation Schemes for Silicon Solar Cells. J. Vac. Sci. Technol. A 2012, 30, 040802.

(48) Han, S.; Flewitt, A. J. The Origin of the High Off-State Current in p-Type $\mathrm{Cu}_{2} \mathrm{O}$ Thin Film Transistors. IEEE Electron Dev. Lett. 2017, 38, 1394-1397.

(49) Gandikota, S.; Voss, S.; Tao, R.; Duboust, A.; Cong, D.; Chen, L.-Y.; Ramaswami, S.; Carl, D. Adhesion Studies of CVD Copper Metallization. Microelectron. Eng. 2000, $50,547-553$.

(50) Uda, M.; Nakamura, A.; Yamamoto, T.; Fujimoto, Y. Work Function of Polycrystalline Ag, Au and Al. J. Electron Spec. 1998, 88-91, $643-648$.

(51) Jagt, R. A.; Huq, T. N.; Hill, S. A.; Thway, M.; Liu, T.; Napari, M.; Roose, B.; Gałkowski, K.; Li, W.; Lin, S. F.; Stranks, S. D.; MacManus-Driscoll, J. L.; Hoye, R. L. Z. Rapid Vapor-Phase Deposition of High-Mobility p-Type Buffer Layers on Per- 
ovskite Photovoltaics for Efficient Semitransparent Devices. ACS Energy Letters 2020, 5, 2456-2465. 


\section{Supporting Information}

\section{Role of $\mathrm{ALD} \mathrm{Al}_{2} \mathrm{O}_{3}$ surface passivation on the performance of p-type $\mathrm{Cu}_{2} \mathrm{O}$ thin film transistors}

Mari Napari ${ }^{1 *}$, Tahmida N. Huq ${ }^{1}$, David J. Meeth ${ }^{2}$, Mikko J. Heikkilä ${ }^{3}$, Kham M. Niang ${ }^{2}$, Han Wang ${ }^{4}$, Tomi Iivonen ${ }^{3 \dagger}$, Haiyan Wang ${ }^{4}$, Markku Leskelä3 ${ }^{3}$ Mikko Ritala $^{3}$, Andrew J. Flewitt ${ }^{2}$, Robert L. Z. Hoye $^{1 \ddagger}$ Judith L. MacManus-Driscoll ${ }^{1}$

${ }^{1}$ Department of Materials Science and Metallurgy, University of Cambridge, UK

${ }^{2}$ Electrical Engineering Division, Department of Engineering, University of Cambridge, UK

${ }^{3}$ Department of Chemistry, University of Helsinki, FIN

${ }^{4}$ School of Materials Engineering, Purdue University, US

m.p.napari@soton.ac.uk

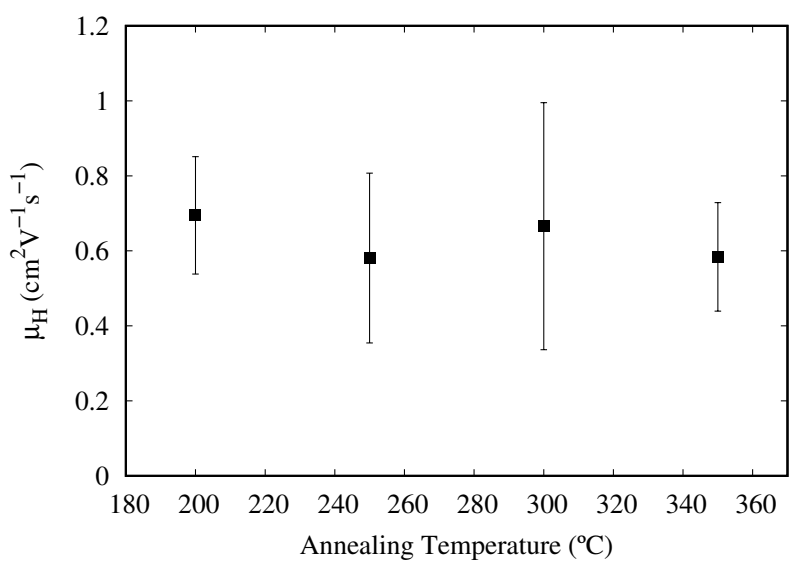

Figure S1: Hall-measured hole mobility $\mu_{\mathrm{H}}$ in the annealed $\mathrm{Cu}_{2} \mathrm{O}$ films. Data point at $200{ }^{\circ} \mathrm{C}$ represents the as-deposited film. The errorbars are the standard deviation of the multiple measurements taken from two samples annealed in same conditions.

*Present address: Zepler institute for Photonics and Nanoelectronics, University of Southampton, Southampton, UK

${ }^{\dagger}$ Present address: Nanoform Finland Oyj, Helsinki, FIN

${ }^{\ddagger}$ Present address: Department of Materials, Imperial College London, UK 

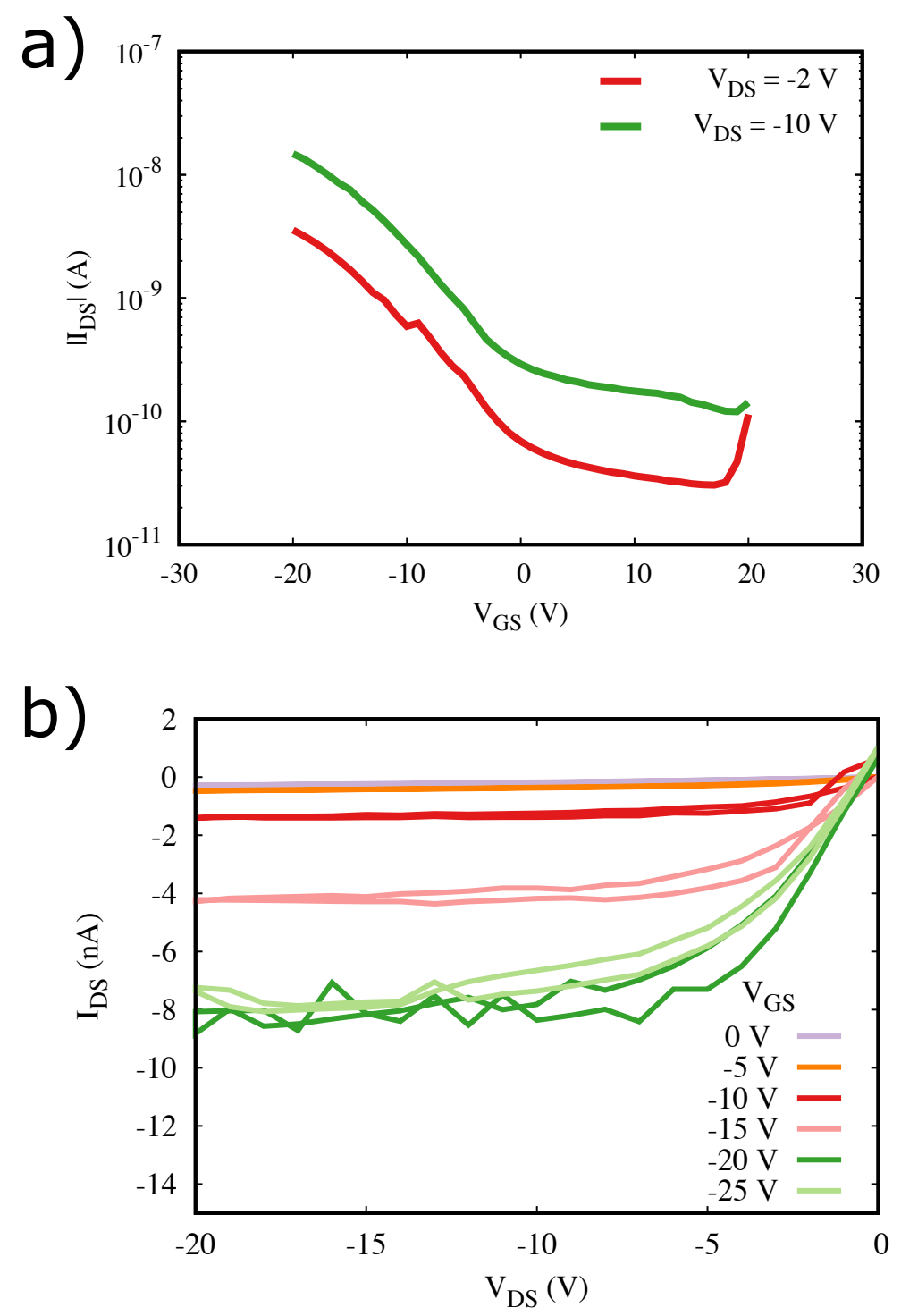

Figure S2: a) Transfer characteristics of a $\mathrm{Cu}_{2} \mathrm{O}$ p-channel TFT with $75 \mathrm{~nm} \mathrm{Al}_{2} \mathrm{O}_{3}$ gate oxide, the device is passivated with $10 \mathrm{~nm} \mathrm{Al}_{2} \mathrm{O}_{3}$ and subsequently annealed at $300{ }^{\circ} \mathrm{C}, \mathrm{W} / \mathrm{L}=20$. (b) TFT output characteristics measured from the same device. 


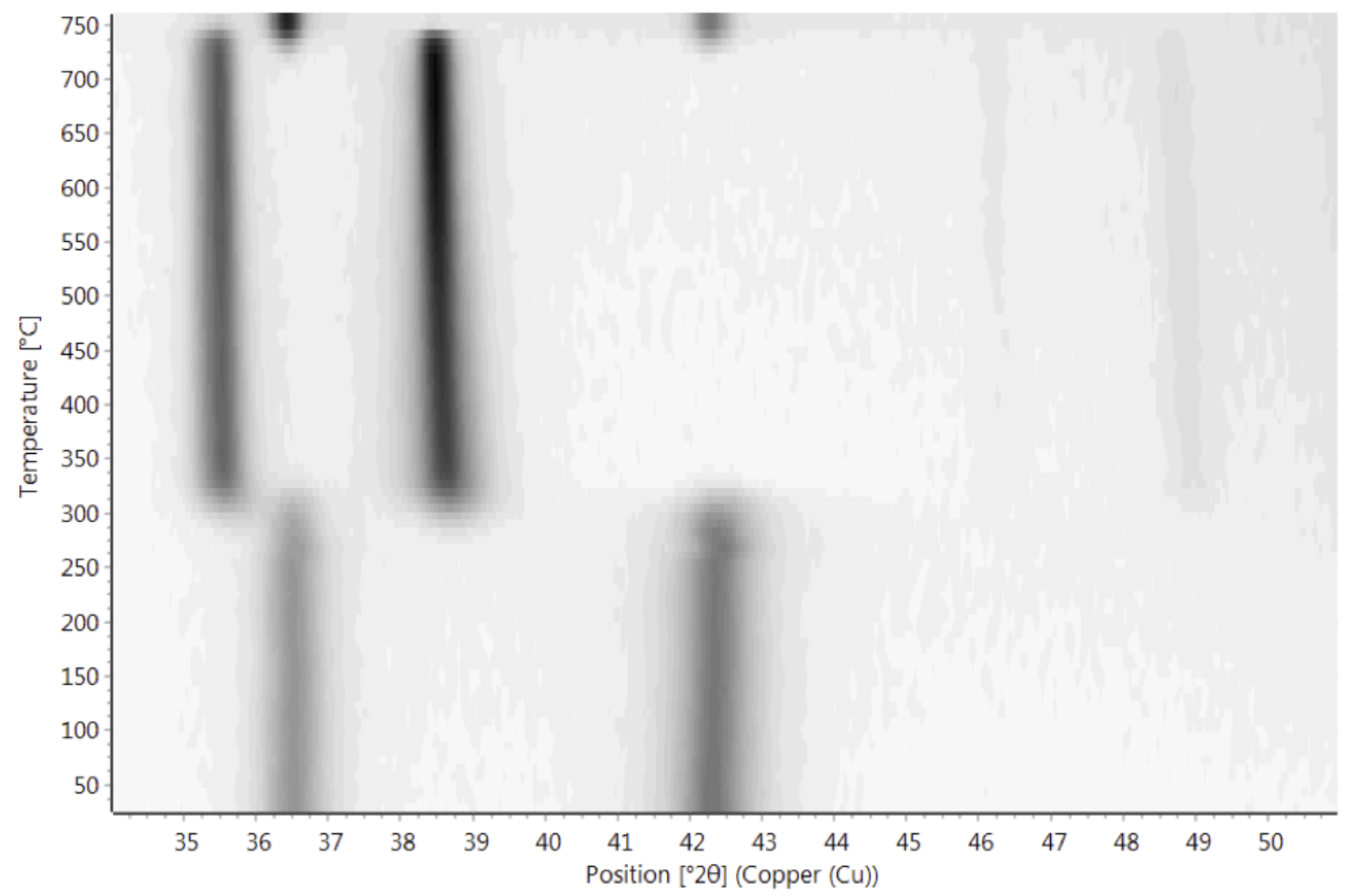

Figure S3: High-temperature GIXRD pattern of an ALD $\mathrm{Cu}_{2} \mathrm{O}$ film measured at 20 mbar N2 (flow $40 \mathrm{sccm}$ ). The $\mathrm{Cu}_{2} \mathrm{O}$ film with most intense reflections (111) at $36.4^{\circ}$ and (200) at $42.3^{\circ}$, oxidises into $\mathrm{CuO}$ at $300{ }^{\circ} \mathrm{C}$, as seen in appearance of $\mathrm{CuO}(002)$ and (111) reflections at $35.4^{\circ}$ and $38.6^{\circ}$, respectively. 

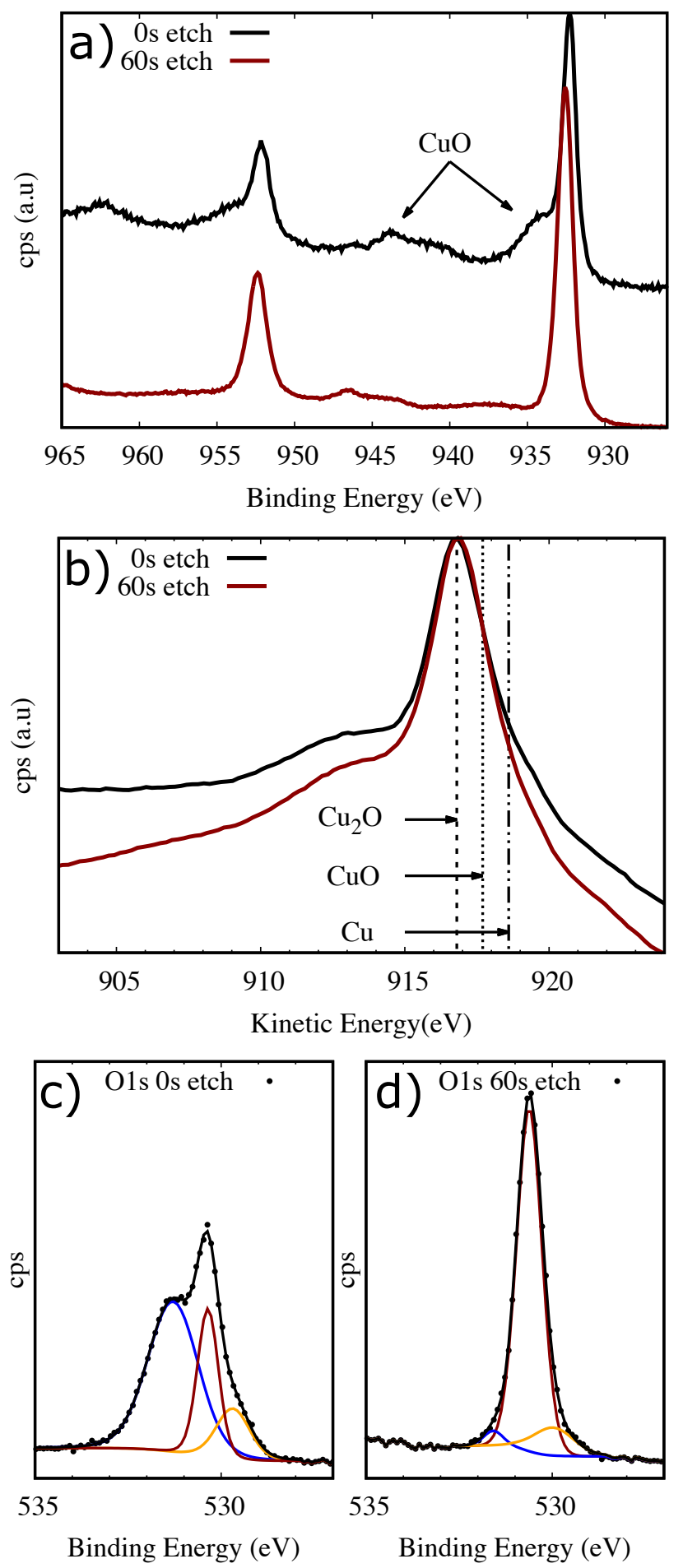

Figure S4: XPS spectra of the as deposited $\mathrm{Cu}_{2} \mathrm{O}$ film, (a) $\mathrm{Cu} 2 \mathrm{p}$, (b) Cu LMM (normalized), (c)\&(d) $\mathrm{O} 1 \mathrm{~s}$, measured after $0 \mathrm{~s}$ and $60 \mathrm{~s}$ of $0.5 \mathrm{keV} \mathrm{Ar}^{+}$sputter surface cleaning. The deconvoluted peaks in (c) and (d) correspond to $\mathrm{Cu}_{2} \mathrm{O}$ lattice oxygen (dark-red), $\mathrm{CuO}$ (orange), and hydroxyl groups (-OH, blue) 

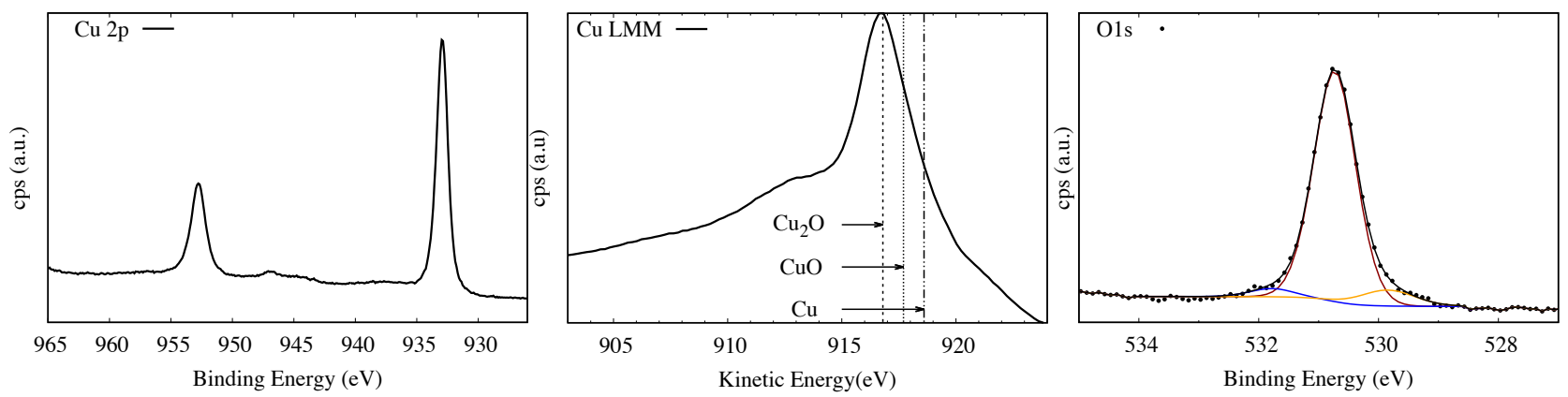

Figure S5: XPS Cu2p, $\mathrm{Cu}$ LMM, and $\mathrm{O}$ 1s spectra of the $\mathrm{Cu}_{2} \mathrm{O}$ film annealed $10 \mathrm{~min}$ in $1.5 \mathrm{mbar}$ at $300{ }^{\circ} \mathrm{C}$, measured after $30 \mathrm{~s} 0.5 \mathrm{keV} \mathrm{Ar}^{+}$sputter surface cleaning.

Table S1: Thermodynamics of oxidation reactions of $\mathrm{Cu}^{0}$ into $\mathrm{Cu}_{2} \mathrm{O}$ and $\mathrm{CuO}$ by $\mathrm{H}_{2} \mathrm{O}$ or $\mathrm{O}_{2}$

(a) $2 \mathrm{Cu}+\mathrm{H}_{2} \mathrm{O}(\mathrm{g})=\mathrm{Cu}_{2} \mathrm{O}+\mathrm{H}_{2}(\mathrm{~g})$

\begin{tabular}{lccc}
\hline $\mathrm{T}\left({ }^{\circ} \mathrm{C}\right)$ & $\Delta \mathrm{H}(\mathrm{kJ})$ & $\Delta \mathrm{S}(\mathrm{J} / \mathrm{K})$ & $\Delta \mathrm{G}(\mathrm{kJ})$ \\
\hline 0 & 73.003 & -32.630 & 81.916 \\
100 & 73.969 & -29.640 & 85.030 \\
200 & 75.132 & -26.886 & 87.853 \\
300 & 76.389 & -24.477 & 90.419 \\
400 & 77.705 & -22.363 & 92.758 \\
500 & 79.054 & -20.494 & 94.899 \\
600 & 80.417 & -18.837 & 96.864 \\
700 & 81.766 & -17.374 & 98.673 \\
800 & 83.071 & -16.097 & 100.345 \\
900 & 84.288 & -15.011 & 101.899 \\
1000 & 85.372 & -14.124 & 103.354 \\
\hline
\end{tabular}

(c) $2 \mathrm{Cu}+\mathrm{O}_{2}(\mathrm{~g})=2 \mathrm{CuO}$

\begin{tabular}{llll}
\hline $\mathrm{T}\left({ }^{\circ} \mathrm{C}\right)$ & $\Delta \mathrm{H}(\mathrm{kJ})$ & $\Delta \mathrm{S}(\mathrm{J} / \mathrm{K})$ & $\Delta \mathrm{G}(\mathrm{kJ})$ \\
\hline 0 & -314.762 & -186.407 & -263.845 \\
100 & -313.941 & -183.909 & -245.315 \\
200 & -312.597 & -180.733 & -227.083 \\
300 & -311.029 & -177.732 & -209.162 \\
400 & -309.350 & -175.033 & -191.526 \\
500 & -307.609 & -172.623 & -174.146 \\
600 & -305.833 & -170.463 & -156.993 \\
700 & -304.045 & -168.524 & -140.046 \\
800 & -302.272 & -166.790 & -123.282 \\
900 & -300.553 & -165.258 & -106.681 \\
1000 & -298.933 & -163.932 & -90.223 \\
\hline
\end{tabular}

(b) $\mathrm{Cu}+\mathrm{H}_{2} \mathrm{O}(\mathrm{g})=\mathrm{CuO}+\mathrm{H}_{2}(\mathrm{~g})$

\begin{tabular}{lccc}
\hline $\mathrm{T}\left({ }^{\circ} \mathrm{C}\right)$ & $\Delta \mathrm{H}(\mathrm{kJ})$ & $\Delta \mathrm{S}(\mathrm{J} / \mathrm{K})$ & $\Delta \mathrm{G}(\mathrm{kJ})$ \\
\hline 0 & 84.200 & -49.639 & 97.759 \\
100 & 85.596 & -45.317 & 102.506 \\
200 & 87.210 & -41.489 & 106.841 \\
300 & 88.896 & -38.257 & 110.823 \\
400 & 90.599 & -35.519 & 114.508 \\
500 & 92.287 & -33.180 & 117.940 \\
600 & 93.941 & -31.169 & 121.155 \\
700 & 95.540 & -29.434 & 124.183 \\
800 & 97.064 & -27.942 & 127.050 \\
900 & 98.490 & -26.671 & 129.779 \\
1000 & 99.792 & -25.605 & 132.391 \\
\hline
\end{tabular}

(d) $4 \mathrm{Cu}+\mathrm{O}_{2}(\mathrm{~g})=2 \mathrm{Cu}_{2} \mathrm{O}$

\begin{tabular}{llll}
\hline $\mathrm{T}\left({ }^{\circ} \mathrm{C}\right)$ & $\Delta \mathrm{H}(\mathrm{kJ})$ & $\Delta \mathrm{S}(\mathrm{J} / \mathrm{K})$ & $\Delta \mathrm{G}(\mathrm{kJ})$ \\
\hline 0 & -337.156 & -152.388 & -295.531 \\
100 & -337.193 & -152.557 & -280.266 \\
200 & -336.752 & -151.526 & -265.058 \\
300 & -336.043 & -150.172 & -249.971 \\
400 & -335.138 & -148.721 & -235.026 \\
500 & -334.075 & -147.251 & -220.228 \\
600 & -332.881 & -145.800 & -205.576 \\
700 & -331.592 & -144.404 & -191.066 \\
800 & -330.259 & -143.099 & -176.692 \\
900 & -328.956 & -141.938 & -162.441 \\
1000 & -327.773 & -140.969 & -148.298
\end{tabular}


a)

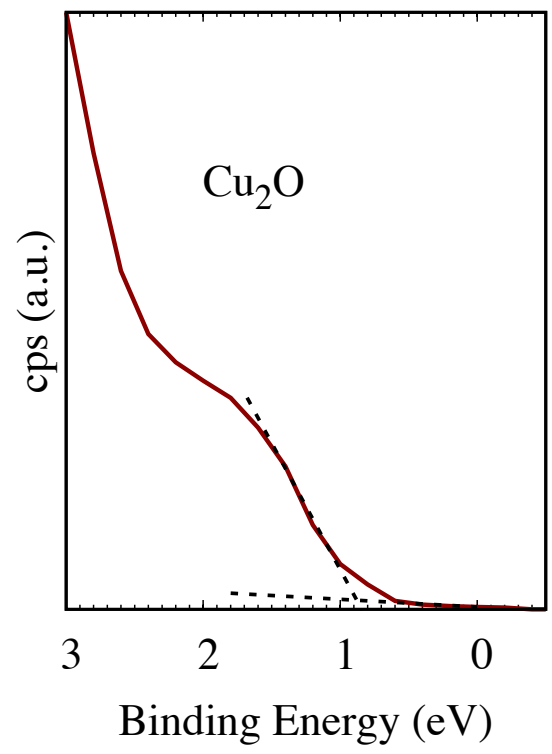

b)

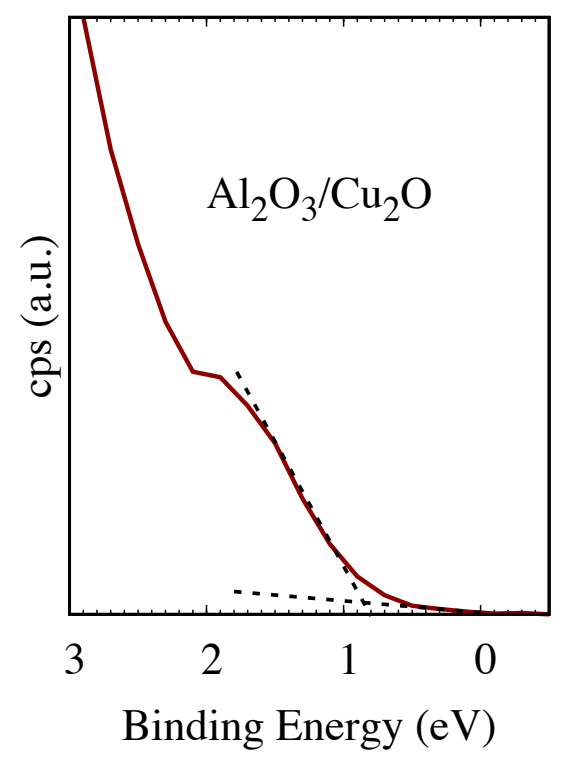

Figure S6: XPS valence edge spectra of a) $\mathrm{Cu}_{2} \mathrm{O}$ film $\left(E_{F}-E_{V B}=0.9 \mathrm{eV}\right)$, and b) $\mathrm{Al}_{2} \mathrm{O}_{3} / \mathrm{Cu}_{2} \mathrm{O}$ interface after a $90 \mathrm{~s}$ sputtering with $0.5 \mathrm{keV} \mathrm{Ar}^{+}\left(E_{F}-E_{V B}=0.9 \mathrm{eV}\right)$

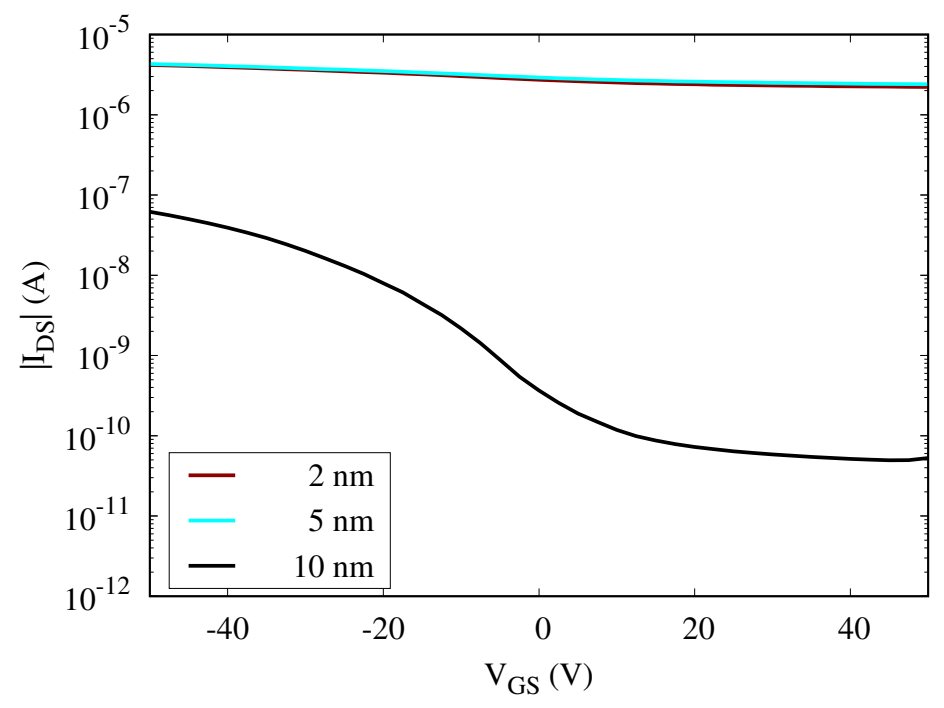

Figure S7: The effect of ALD $\mathrm{Al}_{2} \mathrm{O}_{3}$ layer thickness on the transfer characteristics of the $\mathrm{Cu}_{2} \mathrm{O}$ pchannel TFTs, all samples were annealed for 10 min at $300{ }^{\circ} \mathrm{C} 1.5$ mbar $\mathrm{N}_{2}$ 

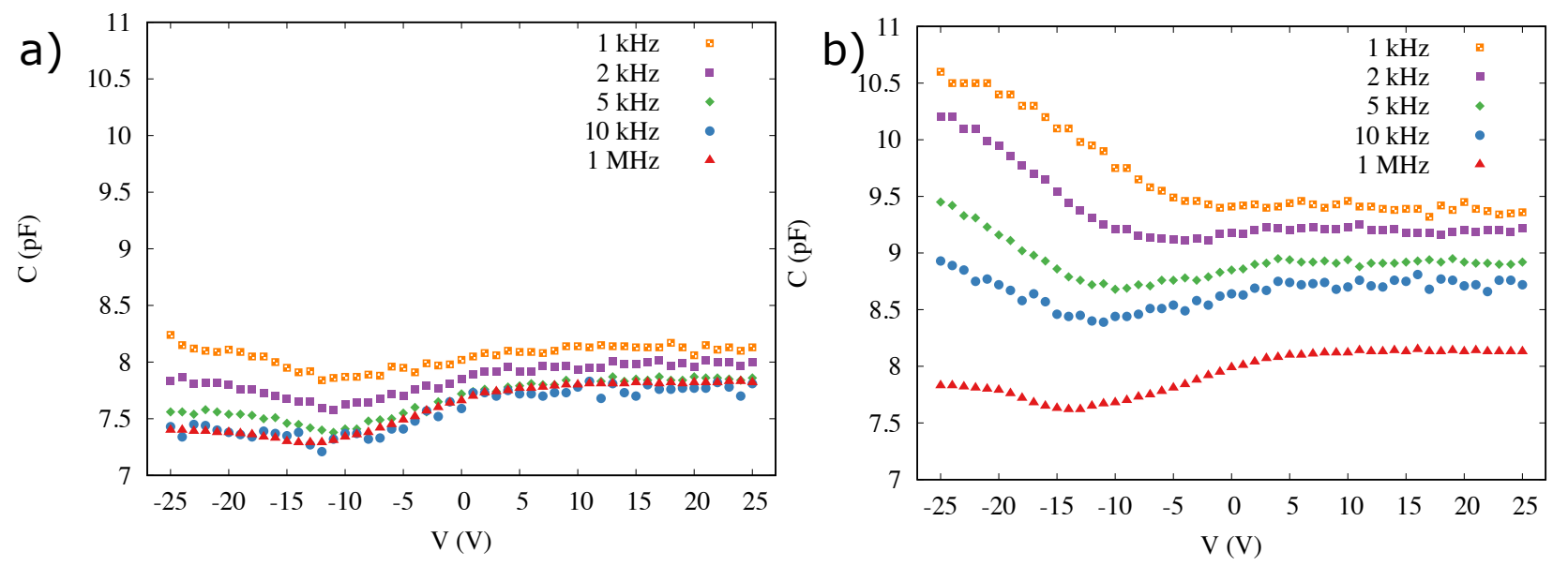

Figure S8: C-V characteristics of the $\mathrm{Cu}_{2} \mathrm{O}$ channel (a) as-deposited, and (b) after $10 \mathrm{~nm} \mathrm{Al}_{2} \mathrm{O}_{3}$ passivation and annealing. The effect of passivation is seen as enhanced hole accumulation at low frequencies. Note: Data measured by coupling the S\&D electrodes and using the common Si gate as a bottom electrode, which leads to highly asymmetric surface areas, and therefore increases the uncertainty of the measured data. 